\title{
Studying the Effect of Paracetamol Drug on the Conductivity of 0.5M Hydrochloric Acid Solution at Different Temperatures
}

\author{
Hadi .Z.Al-Sawaad* \\ *University of Basra, College of Science, Chemistry Department \\ Email: hz.1974@yahoo.com \\ mobile: +9647801131734
}

\begin{abstract}
:
In this study paracetamol drug is used to reduce the conductivity of $0.5 \mathrm{M}$ hydrochloric acid at different concentrations for each one of them at different temperatures ranged $(30-60)^{\circ} \mathrm{C}$. Generally, increasing of the concentration of the inhibitor leads to reducing in conductivity of the acid at constant temperature. On the other hand, at constant concentration of inhibitor, the conductivity is reduced as temperature increased i.e., paracetamol can adsorbed chemically on the metal or alloy. Furthermore the kinetic study of the molar conductance process reveal that in presence of paracetamol the activation energy and enthalpy of activation are negative compared with their values in absence of paracetamol where they are negative because the reducing the conductivity in presence of paracetamol where the non spontaneous property for the conductance of acid is increased as the paracetamol concentration increased in addition to increasing the negative value of entropy in presence of paracetamol that indicate to restrict for the mobility of hydrogen and chloride ions which correspond to $90.47 \%$ as efficiency of reducing the conductance of acid by paracetamol. On the other hand thermodynamic study is achieved which explained the adsorption of paracetamol obey to Freundlisch model.
\end{abstract}

Keywords: molar conductance, adsorption isotherms, paracetamol, corrosion Inhibitors, Hydrochloric acid.

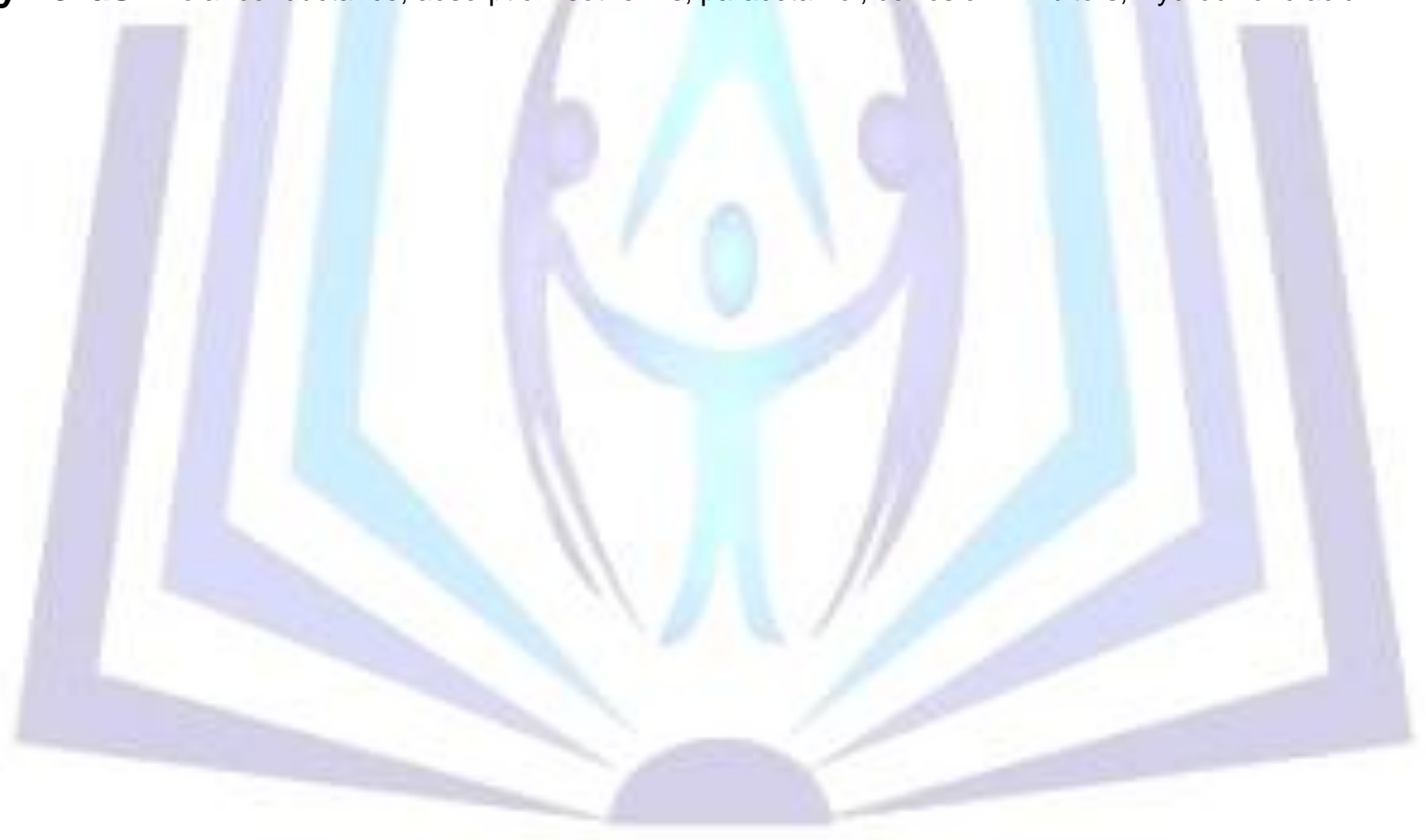

\section{Council for Innovative Research}

Peer Review Research Publishing System

Journal: INTERNATIONAL JOURNAL OF COMPUTERS \& TECHNOLOGY

Vol. 11, No. 7

editor@cirworld.com

www.cirworld.com, member.cirworld.com 


\section{Introduction:}

Acid pickling baths are employed to remove undesirable scale from the surface of the metals. Once the scale is removed, the acid is then free for further attack on the metal surface. Hence, several organic compounds containing $\mathrm{N}, \mathrm{O}$ and $S$ have been studied as corrosion inhibitors by several authors [1,2]. The use of organic compounds with hetero atoms based corrosion inhibitors is often associated with chemical and/or physical adsorption, involving a variation in the charge of adsorbed substance and a transfer of charge from one phase to the other [3]. Special attention was paid to the effect of electron donating atom and electron

With drawing groups which are responsible for adsorption and hence on the performance [4]. Furthermore, it has been observed that the adsorption mainly depends on steric factor, aromaticity and structural properties of the organic compounds, which induce greater adsorption of the inhibitor molecules onto the surface of the metal $[5,6]$. Synergistic corrosion inhibitor plays an important role both in theoretical and practical research [7,9]. Synergistic inhibition effects of organic inhibitor/metallic ion mixture and organic inhibitors/organic inhibitor mixture on the corrosion metal in acid media have also been reported[10-12]. Evaluation of corrosion inhibitors for mild steel in acidic media is important for both theoretical as well as industrial point of views. Acid solutions are generally used for the removal of rust and scale in industrial processes. Hydrochloric acid is widely used in the pickling, cleaning and descaling of steel and ferrous alloys[13]. Thus, mineral acid solutions such as hydrochloric acid are widely used for various treatments of materials in industry[14,15]. The corrosion of metallic materials in acidic solution causes considerable costs. In order to reduce the corrosion of metals, several techniques have been applied. The use of inhibitors during acid pickling procedure is one of the most practical methods for protection against corrosion in acidic media[16]. Hence, inhibitors are used to reduce the rate of dissolution of metals by using compounds containing $\mathrm{N}, \mathrm{S}$, and $\mathrm{O}$ atoms have been reported as excellent inhibitors[17]. Conductivity measurements are widely used in industry. Some important applications are described like water treatment, Raw water as it comes from a lake, river, or the tap is rarely suitable for industrial use. The water contains contaminants, largely ionic, that if not removed will cause scaling and corrosion in plant equipment, particularly in heat exchangers, cooling towers, and boilers[18]. Conductivity is typically measured in aqueous solutions of electrolytes. Electrolytes are substances containing ions, i.e. solutions of ionic salts or of compounds that ionize in solution. The ions formed in solution are responsible for carrying the electric current. Electrolytes include acids, bases and salts and can be either strong or weak. Most conductive solutions measured are aqueous solutions, as water has the capability of stabilizing the ions formed by a process called solvation. As a result, the concentration of ions in solution is proportional to the concentration of the electrolyte added. They include ionic solids and strong acids, for example $\mathrm{HCl}$. Solutions of strong electrolytes conduct electricity because the positive and negative ions can migrate largely independently under the influence of an electric field[19]. Paracetamol (acetaminophen) is commonly used as an analgesic and antipyretic drug in pharmaceutical formulations solely or in the mixtures with a few contaminants, typically caffeine, acetylsalicylic acid and some others. It is extensively used in the treatment of mild to moderate pain and fever and available without a prescription. Overdose of paracetamol can lead to hepatic necrosis or renal failure[20].

In this study the paracetamol drug at different concentrations i.e., (10-50)ppm were prepared as inhibitor for the conductivity of $0.50 \mathrm{M} \mathrm{HCl}$ at constant temperature. On the other hand, the effect of temperature on the inhibition effect of paracetamol against the conductivity of the $0.50 \mathrm{M} \mathrm{HCl}$ at constant concentration was studied at range $(30-60){ }^{\circ} \mathrm{C}$ in order to evaluate the paracetamol as a corrosion inhibitor for steel or other alloy or metals depending on the reducing of the conductivity of the corrosive environment like acid i.e., $0.50 \mathrm{M} \mathrm{HCl}$. Thus, the molar conductivity is used in this study because the concentration of electrolyte (corrosive environment) is taken into account.

\section{Experimental part:}

After the extraction of additives from a paracetamol by using a methanol as solvent, a stock solution of purified Paracetamol $(1000 \mathrm{ppm})$ was prepared by dissolving $1 \mathrm{~g}$ of paracetamol in $1 \mathrm{~L}$ of $0.50 \mathrm{M} \mathrm{HCl}$ as a solvent then, a different concentrations of paracetamol is prepared (10-50)ppm by using $0.50 \mathrm{M} \mathrm{HCl}$ as a solvent to study their role on the molar conductance of $0.5 \mathrm{M}$ hydrochloric acid in addition to study the effect of temperature on the molar conductance of hydrochloric acid in presence and absence of paracetamol. The structure of paracetamol( $N$ - $(4-$ hydroxyphenyl) acetamide is show below in Figure 1:<smiles>CC(=O)Nc1ccc(O)cc1</smiles>

Figure 1: Structure of Paracetamol ( $\mathrm{N}-(4-$ hydroxyphenyl)acetamide).

Then the conductivity of $0.50 \mathrm{M} \mathrm{HCl}$ is measured in the absence and presence of different concentration of paracetamol i.e., $(10-50) \mathrm{ppm}$ at different temperatures where, the conductivity of distilled water at the temperatures ranged $(30-60)^{\circ} \mathrm{C}$ is subtracted from the conductivity of $0.50 \mathrm{M} \mathrm{HCl}$ solutions whether in presence or absence of paracetamol. On the other hand, the cell constant values of the conductance cell is measured experimentally by using $0.1 \mathrm{M} \mathrm{KCl}$ solution at different temperatures ranged $(30-60){ }^{\circ} \mathrm{C}$ as shown in Table 1 : 
Table1: The cell constant relative to $0.10 \mathrm{M}$ potassium chloride solution at different temperatures:

\begin{tabular}{|l|l|}
\hline Cell constant.cm & -1 \\
\hline 0.91 & 30 \\
\hline 0.85 & 40 \\
\hline 0.80 & 50 \\
\hline 0.71 & 60 \\
\hline
\end{tabular}

Thus, the study of the effect of concentrations of paracetamol on the molar conductance of the mentioned acid at constant temperature and the revrse can be explained as in results below:

\section{Results and Discussions:}

\section{Study the effect of concentration of paracetamol on the molar conductance of $0.50 \mathrm{M} \mathrm{HCl}$ at constant temperatures:}

The conductivity of the $0.5 \mathrm{M}$ hydrochloric acid is measured in absence and presence of paracetamol relative to the conductivity of the distilled water according to the following equation:

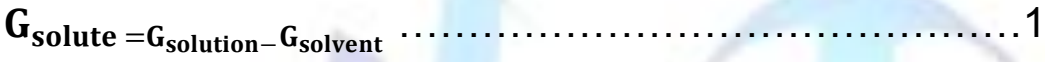

Where $G$ is the conductivity in $G_{\text {solute }}, G_{\text {solution }}$ and $G_{\text {solvent }}$ are the conductivity in $\Omega^{-1}$ (Semins) for the $0.50 \mathrm{M} \mathrm{HCl}$, the conductivity for the solution and the conductivity for the solvent respectively. On the other hand the specific conductance for the hydrochloric acid solution is measured according to the following equation:

$\boldsymbol{\kappa}_{\text {solute }}=\mathbf{A} \times \mathbf{G}_{\text {solute }}$

Where $\mathrm{K}$ is the specific conductance of the solute in $\Omega^{-1} \cdot \mathrm{cm}^{-1}$. Hence, the molar conductance is calculated according to the following equation:

$$
\Lambda_{\operatorname{molar}}=\frac{10^{3} \times \kappa}{C}
$$

Where $\Lambda_{\text {molar }}$ is the molar conductance in $\Omega^{-1} \cdot \mathrm{mol}^{-1} \cdot \mathrm{cm}^{2}$ and $\mathrm{C}$ is the concentration of the hydrochloric acid respectively where $C=0.50 \mathrm{M}$ thus, the concentrations of paracetamol is used to study the effect of paracetamol on the conductivity of hydrochloric acid. In fact, the study of the molar conductance is used due to it express to the real conductivity for electrolyte i.e., hydrochloric acid because, it take into account the concentration of the electrolyte. Thus, the reducing in molar conductivity of the acid can be calculated according to the following equation :

$$
\boldsymbol{E} \boldsymbol{f} \boldsymbol{f} \%=\frac{\Lambda_{\text {Blank }}-\Lambda_{\text {Inhibitor }}}{\Lambda_{\text {Blank }}} \times 100 \ldots \ldots \ldots \ldots \ldots
$$

Where efficiency $\%$ is the efficiency of paracetamol to reduce the molar conductance of hydrochloric acid, $\Lambda_{\text {Blank }}$ and $\Lambda_{\text {Inhibitor }}$ are the molar conductance of hydrochloric acid in absence and presence of paracetamol as inhibitor respectively. On the other hand, the ionic mobility can be calculated for the hydrochloric acid according to the following equations:

$\boldsymbol{U}=\frac{\Lambda}{\boldsymbol{F}}$

Where $\mathrm{U}$ is the ionic mobility $\mathrm{m}^{2} \cdot \mathrm{s}^{-1} \cdot \mathrm{V}^{-1}$ for hydrochloric acid and $\mathrm{F}$ is Faraday's constant $\left(96500 \mathrm{Coloumb}^{-1} \mathrm{~mol}^{-1}\right)$. Hence the efficiency and the ionic mobility can be listed as in Tables (2-5) as below:

Table 2 : The molar conductance of $0.50 \mathrm{M} \mathrm{HCl}$ in presence of different concentrations of paracetamol compared with hydrochloric acid alone at $30^{\circ} \mathrm{C}$.

\begin{tabular}{|r|l|l|l|l|}
\hline Compound & Conc. $(\mathrm{ppm})$ & $N \Omega^{-1} \mathrm{~mol}^{-1} \cdot \mathrm{cm}^{2}$ & $\mathrm{U} / \mathrm{m}^{2} \mathrm{~s}^{-1} \cdot \mathrm{V}^{-1} \times 10^{-4}$ & $\mathrm{Eff} \%$ \\
\hline Hydrochloric acid & 18250 & 388.8 & 40.29 & - \\
\hline paracetamol & 10 & 72.8 & 7.54 & 81.21 \\
\hline paracetamol & 20 & 69.2 & 7.17 & 82.14 \\
\hline paracetamol & 30 & 63.8 & 6.61 & 83.53 \\
\hline paracetamol & 40 & 60.0 & 6.23 & 84.50 \\
\hline paracetamol & 50 & 56.40 & 5.84 & 85.43 \\
\hline
\end{tabular}


Table 3: The molar conductance of $0.50 \mathrm{M} \mathrm{HCl}$ in presence of different concentrations of paracetamol compared with hydrochloric acid alone at $40^{\circ} \mathrm{C}$.

\begin{tabular}{|c|l|l|l|l|}
\hline Compound & Conc. $(\mathrm{ppm})$ & $\Lambda / \Omega^{-1} \mathrm{~mol}^{-1} \cdot \mathrm{cm}^{2}$ & $\mathrm{U} / \mathrm{m}^{2} \mathrm{~s}^{-1} \cdot \mathrm{V}^{-1} \times 10^{-4}$ & Eff\% \\
\hline Hydrochloric acid & 18250 & 438.9 & 45.48 & - \\
\hline paracetamol & 10 & 71.4 & 7.40 & 83.79 \\
\hline paracetamol & 20 & 66.4 & 6.88 & 84.93 \\
\hline paracetamol & 30 & 61.2 & 6.34 & 86.12 \\
\hline paracetamol & 40 & 57.8 & 5.99 & 86.89 \\
\hline paracetamol & 50 & 54.4 & 5.64 & 87.67 \\
\hline
\end{tabular}

Table 4: The molar conductance of $0.50 \mathrm{M} \mathrm{HCl}$ in presence of different concentrations of paracetamol compared with hydrochloric acid alone at $50^{\circ} \mathrm{C}$.

\begin{tabular}{|r|l|l|l|l|}
\hline Compound & Conc. $(\mathrm{ppm})$ & $N / \Omega^{-1} \mathrm{~mol}^{-1} \cdot \mathrm{cm}^{2}$ & $\mathrm{U} / \mathrm{m}^{2} \mathrm{~s}^{-1} \cdot \mathrm{V}^{-1} \times 10^{-4}$ & $\mathrm{Eff} \%$ \\
\hline Hydrochloric acid & 18250 & 484.4 & 50.20 & - \\
\hline paracetamol & 10 & 68.8 & 7.13 & 85.61 \\
\hline paracetamol & 20 & 64.0 & 6.63 & 86.60 \\
\hline paracetamol & 30 & 60.8 & 6.30 & 87.26 \\
\hline paracetamol & 40 & 57.6 & 5.97 & 87.92 \\
\hline paracetamol & 50 & 52.6 & 5.45 & 89.38 \\
\hline
\end{tabular}

Table 5: The molar conductance of $0.50 \mathrm{M} \mathrm{HCl}$ in presence of different concentrations of paracetamol compared with hydrochloric acid alone at $60^{\circ} \mathrm{C}$.

\begin{tabular}{|r|l|l|l|l|}
\hline Compound & Conc. $(\mathrm{ppm})$ & $\mathrm{N} \mathrm{\Omega}^{-1} \mathrm{~mol}^{-1} \cdot \mathrm{cm}^{2}$ & $\mathrm{U} / \mathrm{m}^{2} \mathrm{~s}^{-1} \cdot \mathrm{V}^{-1} \times 10^{-4}$ & $\mathrm{Eff} \%$ \\
\hline Hydrochloric acid & 18250 & 533.4 & 55.27 & - \\
\hline paracetamol & 10 & 63.8 & 6.61 & 87.82 \\
\hline paracetamol & 20 & 59.4 & 6.16 & 88.64 \\
\hline paracetamol & 30 & 55.2 & 5.72 & 89.42 \\
\hline paracetamol & 40 & 53.8 & 5.58 & 89.68 \\
\hline paracetamol & 50 & 49.6 & 5.14 & 90.47 \\
\hline
\end{tabular}

From the above tables the ionic mobility of the acid is reduced as the concentration of paracetamol is increased which leads to reduce in its molar conductivity this can be attributed to the increasing the ability of paracetamol as its concentration is increased to retard the mobility of the hydrogen and chloride ions for hydrochloric acid toward the their oppose electrodes where the increasing of inhibition efficiency of paracetamol is increased as its concentration is increased hence, paracetamol can be evaluated as corrosion inhibitor for a certain metal or alloy due to its ability to reduce the ionic mobility of hydrochloric acid i.e., reducing the evolution of hydrogen gas on the cathode or on the metal surface if immersed in $\mathrm{HCl}$ solution i.e., reduce in molar conductance of hydrochloric acid. Thus, the results of the maximum inhibition efficiency about $90.47 \%$ which approximately correspond with another study for using a paracetamol as corrosion inhibitor for mild steel alloy in sulfuric acid where, the maximum efficiency for a paracetamol is $85 \%$ [21]. The relation between efficiency and concentration of paracetamol can be shown as in Figures (2-5) below: 


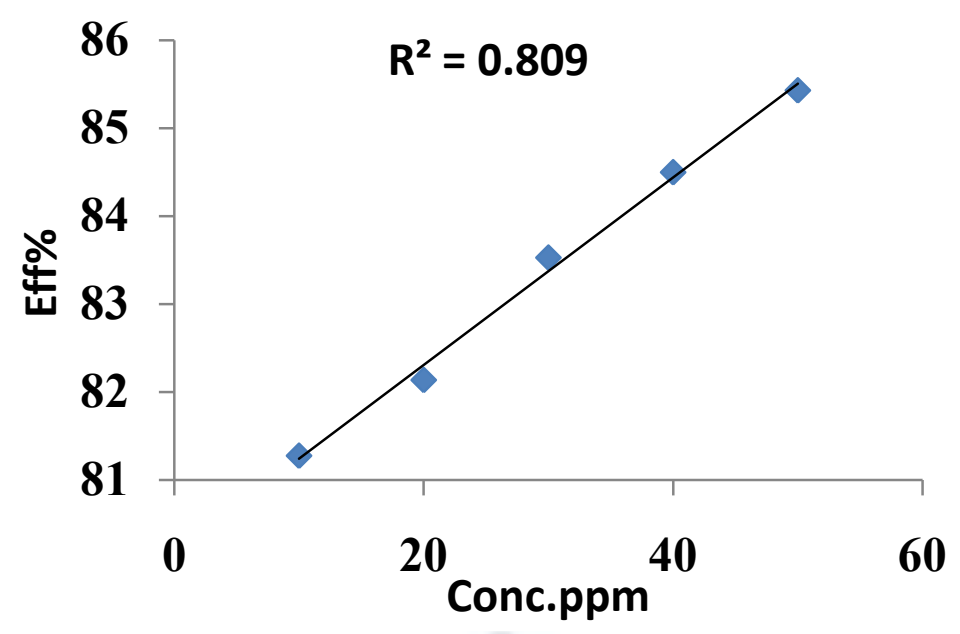

Figure 2: The relation between inhibition efficiency of Paracetamol and its concentrations against the molar conductance of $0.5 \mathrm{M} \mathrm{HCl}$ at $30^{\circ} \mathrm{C}$.

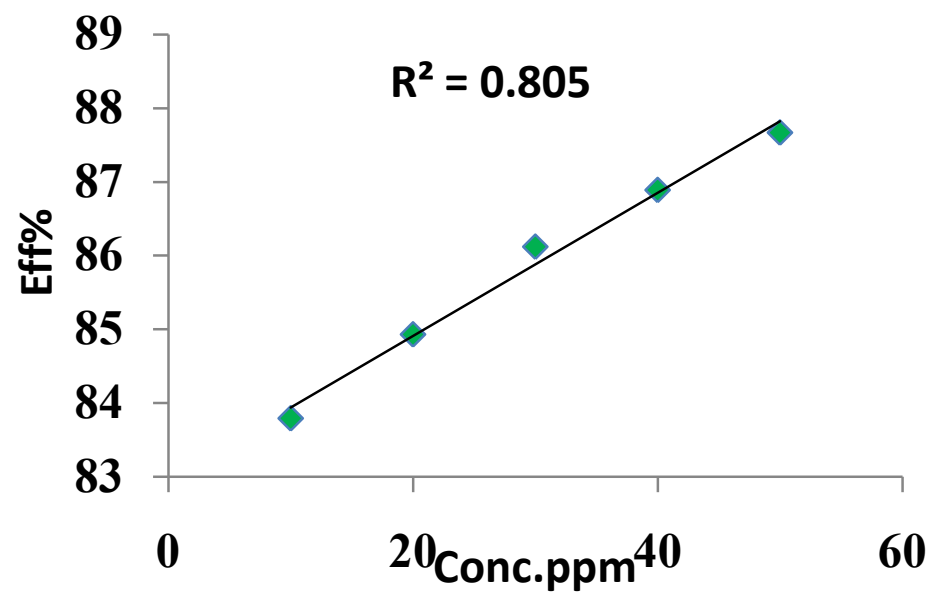

Figure 3: The relation between inhibition efficiency of Paracetamol and its concentrations against the molar conductance of $0.5 \mathrm{M} \mathrm{HCl}$ at $40^{\circ} \mathrm{C}$.

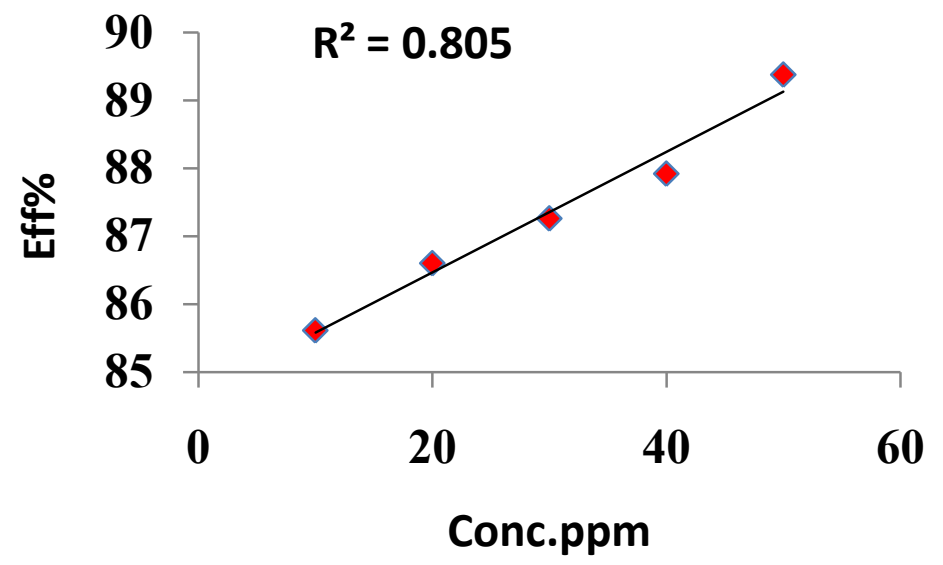

Figure 5: The relation between inhibition efficiency of Paracetamol and its concentrations against the molar conductance of $0.5 \mathrm{M} \mathrm{HCl}$ at $50^{\circ} \mathrm{C}$. 


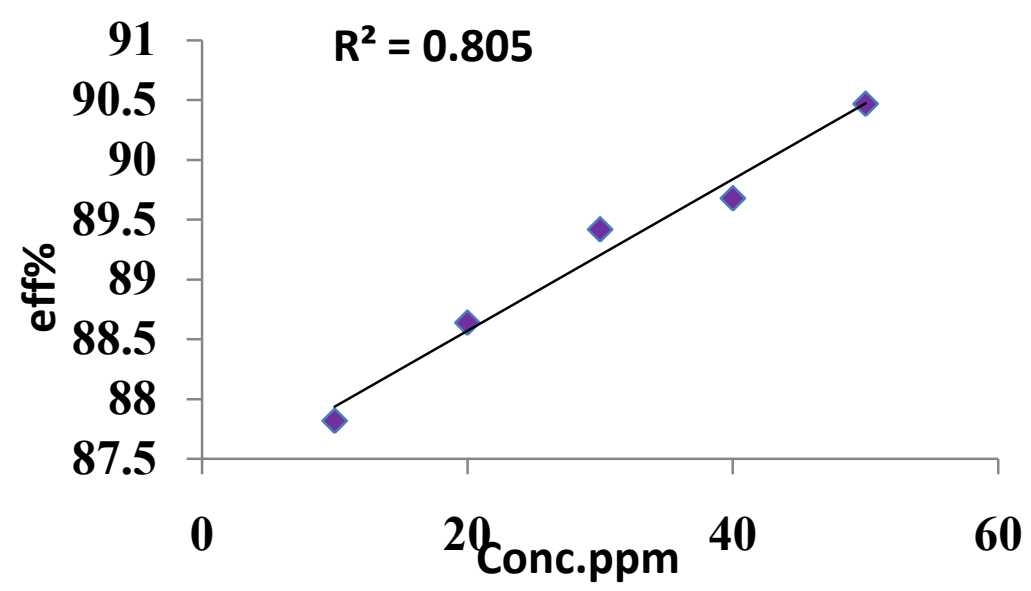

Figure 6: The relation between inhibition efficiency of Paracetamol and its concentrations against the molar conductance of $0.5 \mathrm{M} \mathrm{HCl}$ at $60^{\circ} \mathrm{C}$.

The relation between efficiency and concentration of paracetamol a different temperatures can be summarized as in Figure 7:

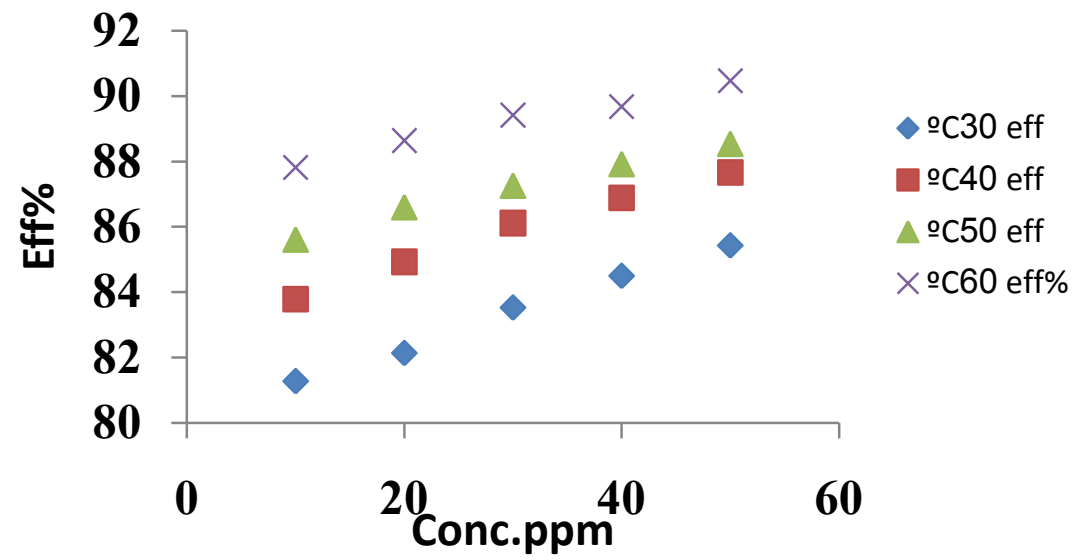

Figure 7: The relation between inhibition efficiency of Paracetamol and its concentrations against the molar conductance of $0.5 \mathrm{M} \mathrm{HCl}$ at different temperatures.

On the other hand, the relation between ionic mobility of hydrochloric acid in presence of different concentration of paracetamol at different temperatures can be shown in Figure 8 where the zero concentration of paracetamol means presence of acid only without paracetamol.

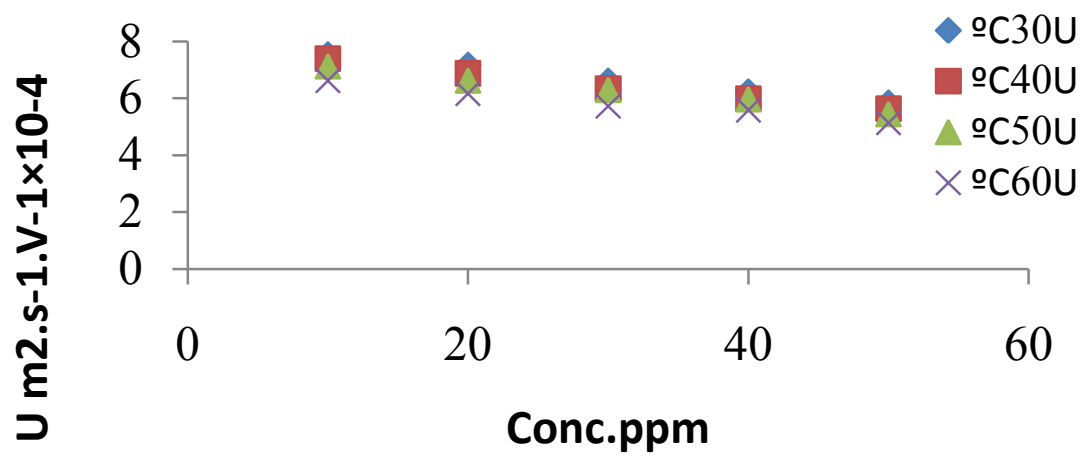

Figure 8: variation of the ionic mobility for $0.5 \mathrm{M} \mathrm{HCl}$ at different concentrations of Paracetamol a different temperatures.

As in Figure 8 above generally, the ionic mobility of hydrochloric acid is reduced as the concentration of paracetamol is increased at different temperatures ranged (30-60) ${ }^{\circ} \mathrm{C}$ especially at $60{ }^{\circ} \mathrm{C}$ this can be attributed to reducing the activation energy of paracetamol to inhibit the mobility of hydrogen and chloride ions toward the oppose electrodes thus, the 
reducing in molar conductance for hydrochloric acid as increasing the concentration of paracetamol will be occurred at the above range of temperatures corresponding to the case of ionic mobility as shown in Figure 9 below:

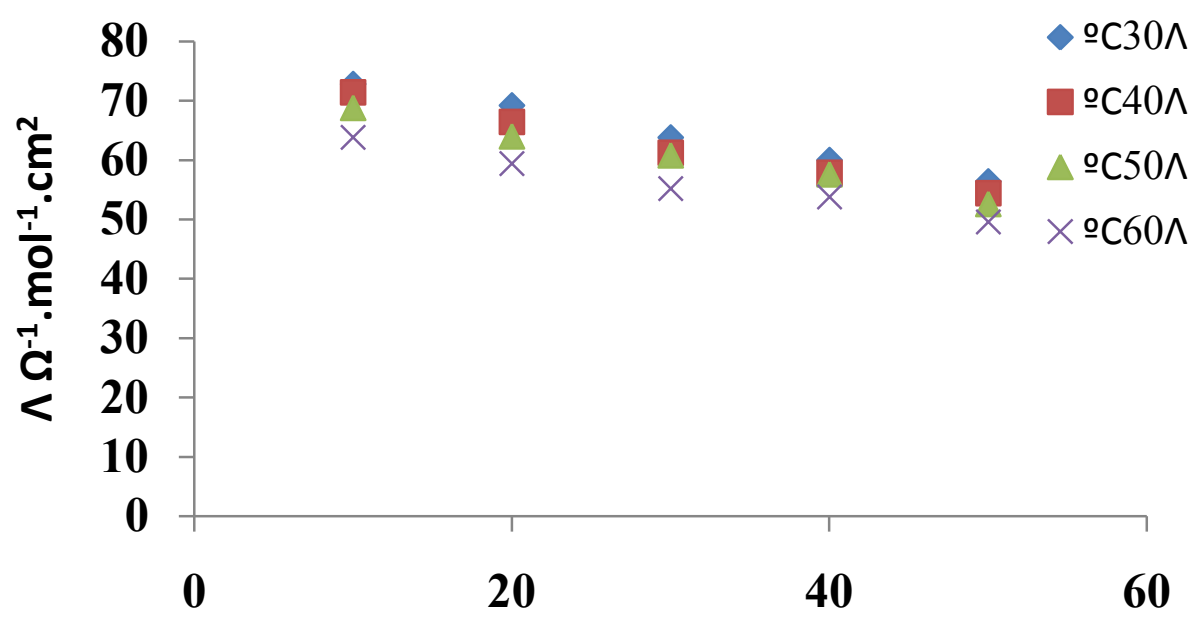

Conc. ppm

Figure 9: variation of Molar conductance for $0.5 \mathrm{M} \mathrm{HCl}$ at different concentrations of Paracetamol a different temperatures.

2. Study the effect of temperature on the molar conductance of $0.50 \mathrm{M} \mathrm{HCl}$ at constant concentration of paracetamol:

The effect of temperature on the molar conductance for $0.5 \mathrm{M} \mathrm{HCl}$ in the presence and absence of paracetamol was studied which can be summarized in Tables (6-11) as below:

Table 6: The effect of temperature on molar conductance of $0.50 \mathrm{M}(18250 \mathrm{ppm}) \mathrm{HCl}$ in absence of paracetamol:

\begin{tabular}{|c|l|l|l|l|}
\hline Compound & Temp. $\left({ }^{\circ} \mathrm{C}\right)$ & $N / \Omega^{-1} \mathrm{~mol}^{-1} \cdot \mathrm{cm}^{2}$ & $\mathrm{U} / \mathrm{m}^{2} \mathrm{~s}^{-1} \cdot \mathrm{V}^{-1} \times 10^{-4}$ & Eff\% \\
\hline Hydrochloric acid & 30 & 388.8 & 40.29 & - \\
\hline Hydrochloric acid & 40 & 438.9 & 45.48 & - \\
\hline Hydrochloric acid & 50 & 484.4 & 50.20 & - \\
\hline Hydrochloric acid & 60 & 533.4 & 55.27 & - \\
\hline
\end{tabular}

Table 7: The effect of temperature on molar conductance of $0.50 \mathrm{M}(18250 \mathrm{ppm}) \mathrm{HCl}$ in presence of 10ppm of paracetamol:

\begin{tabular}{|c|l|l|l|l|}
\hline Compound & Temp. $\left({ }^{\circ} \mathrm{C}\right)$ & $N \Omega^{-1} \mathrm{~mol}^{-1} \cdot \mathrm{cm}^{2}$ & $\mathrm{U} / \mathrm{m}^{2} \mathrm{~s}^{-1} \cdot \mathrm{V}^{-1} \times 10^{-4}$ & Eff\% \\
\hline paracetamol & 30 & 72.8 & 7.54 & 81.21 \\
\hline paracetamol & 40 & 71.4 & 7.40 & 83.79 \\
\hline paracetamol & 50 & 68.8 & 7.13 & 85.61 \\
\hline paracetamol & 60 & 63.8 & 6.61 & 87.82 \\
\hline
\end{tabular}

Table 8: The effect of temperature on molar conductance of $0.50 \mathrm{M}(18250 \mathrm{ppm}) \mathrm{HCl}$ in presence of 20ppm of paracetamol:

\begin{tabular}{|c|l|l|l|l|}
\hline Compound & Temp. $\left({ }^{\circ} \mathrm{C}\right)$ & $N \Omega^{-1} \mathrm{~mol}^{-1} \cdot \mathrm{cm}^{2}$ & $\mathrm{U} / \mathrm{m}^{2} \mathrm{~s}^{-1} \cdot \mathrm{V}^{-1} \times 10^{-4}$ & $\mathrm{Eff} \%$ \\
\hline paracetamol & 30 & 69.2 & 7.17 & 82.14 \\
\hline paracetamol & 40 & 66.4 & 6.88 & 84.93 \\
\hline paracetamol & 50 & 64.0 & 6.63 & 86.60 \\
\hline paracetamol & 60 & 59.4 & 6.16 & 88.64 \\
\hline
\end{tabular}


Table 9: The effect of temperature on molar conductance of $0.50 \mathrm{M}(18250 \mathrm{ppm}) \mathrm{HCl}$ in presence of 30ppm of paracetamol:

\begin{tabular}{|c|l|l|l|l|}
\hline Compound & Temp. $\left({ }^{\circ} \mathrm{C}\right)$ & $N / \Omega^{-1} \mathrm{~mol}^{-1} \cdot \mathrm{cm}^{2}$ & $\mathrm{U} / \mathrm{m}^{2} \mathrm{~s}^{-1} \cdot \mathrm{V}^{-1} \times 10^{-4}$ & Eff\% \\
\hline paracetamol & 30 & 63.8 & 6.61 & 83.53 \\
\hline paracetamol & 40 & 61.2 & 6.34 & 86.12 \\
\hline paracetamol & 50 & 60.8 & 6.30 & 87.26 \\
\hline paracetamol & 60 & 55.2 & 5.72 & 89.42 \\
\hline
\end{tabular}

Table 10 : The effect of temperature on molar conductance of $0.50 \mathrm{M}(18250 \mathrm{ppm}) \mathrm{HCl}$ in presence of $40 \mathrm{ppm}$ of paracetamol:

\begin{tabular}{|c|l|l|l|l|}
\hline Compound & Temp. $\left({ }^{\circ} \mathrm{C}\right)$ & $N \Omega^{-1} \mathrm{~mol}^{-1} \cdot \mathrm{cm}^{2}$ & $\mathrm{U} / \mathrm{m}^{2} \mathrm{~s}^{-1} \cdot \mathrm{V}^{-1} \times 10^{-4}$ & $\mathrm{Eff} \%$ \\
\hline paracetamol & 30 & 60.0 & 6.23 & 84.50 \\
\hline paracetamol & 40 & 57.8 & 5.99 & 86.89 \\
\hline paracetamol & 50 & 57.6 & 5.97 & 87.92 \\
\hline paracetamol & 60 & 53.8 & 5.58 & 89.68 \\
\hline
\end{tabular}

Table 11: The effect of temperature on molar conductance of $0.50 \mathrm{M}(18250 \mathrm{ppm}) \mathrm{HCl}$ in presence of 50ppm of paracetamol:

\begin{tabular}{|c|l|l|l|l|}
\hline Compound & Temp. $\left({ }^{\circ} \mathrm{C}\right)$ & $N \Omega^{-1} \mathrm{~mol}^{-1} \cdot \mathrm{cm}^{2}$ & $\mathrm{U} / \mathrm{m}^{2} \mathrm{~s}^{-1} \cdot \mathrm{V}^{-1} \times 10^{-4}$ & Eff\% \\
\hline paracetamol & 30 & 56.40 & 5.84 & 85.43 \\
\hline paracetamol & 40 & 54.4 & 5.64 & 87.67 \\
\hline paracetamol & 50 & 52.6 & 5.45 & 89.38 \\
\hline paracetamol & 60 & 49.6 & 5.14 & 90.47 \\
\hline
\end{tabular}

As shown from the above tables the molar conductance of acid is increased as temperature increased due to the ionic mobility for acid ions is increased as in Table 6 but, when a paracetamol is added at different concentrations i.e.,(1050)ppm Tables (7-11), each one of the mentioned concentrations reduced the molar conductance of acid because , the ionic mobility of acid is reduced in presence of paracetamol where the efficiency of inhibition of conductivity is increased. Furthermore, the highest concentration of paracetamol has he higher ability to reduce the molar conductance of acid compared with lowest concentration as in Tables (7-11). The relation between ionic mobility of acid and temperatures can be shown as in Figures (10-15) below:

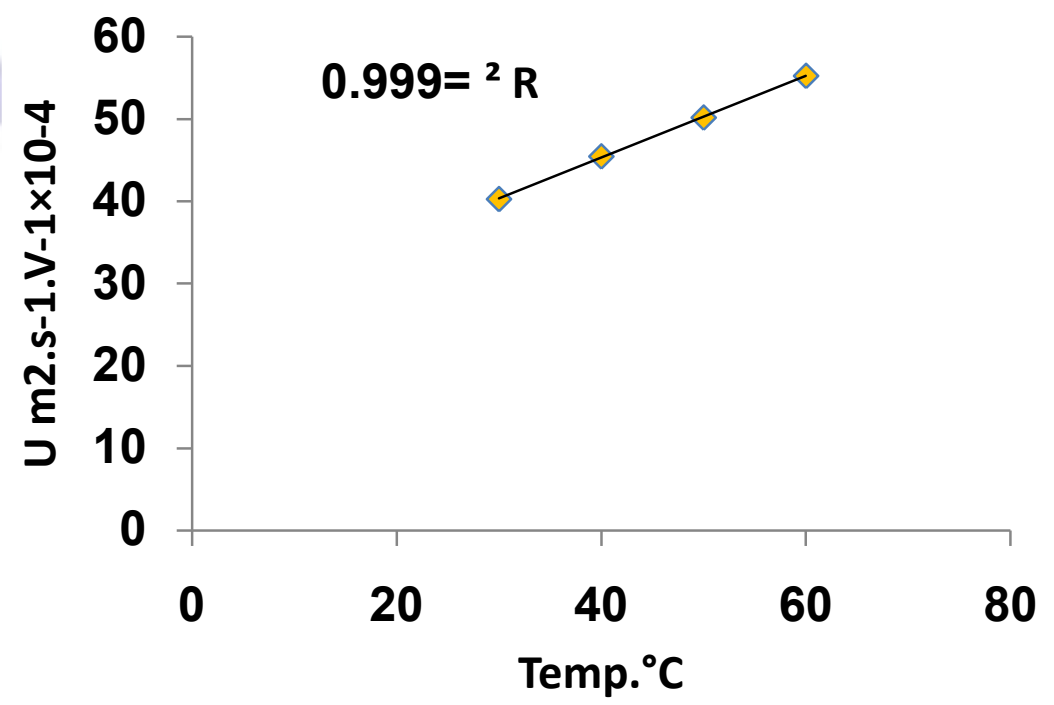

Figure 10: Variation of ionic mobility of $0.5 \mathrm{M} \mathrm{HCl}$ with temperature in absence of paracetamol. 


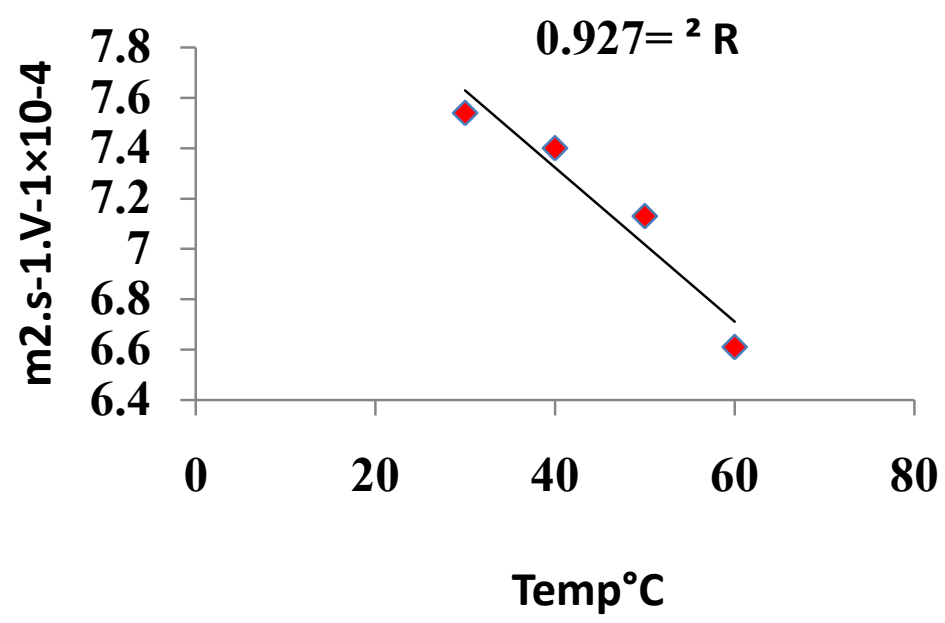

Figure 11: Variation of ionic mobility of $0.5 \mathrm{M} \mathrm{HCl}$ with temperature in presence of $10 \mathrm{ppm}$ paracetamol.

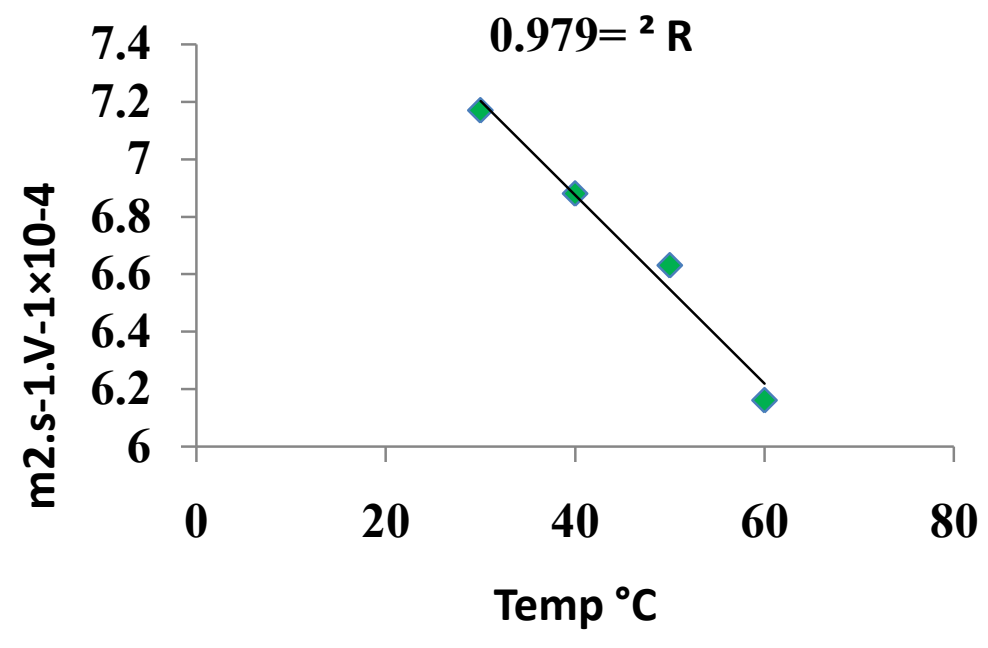

Figure 12: Variation of ionic mobility of $0.5 \mathrm{M} \mathrm{HCl}$ with temperature in presence of $20 \mathrm{ppm}$ paracetamol.

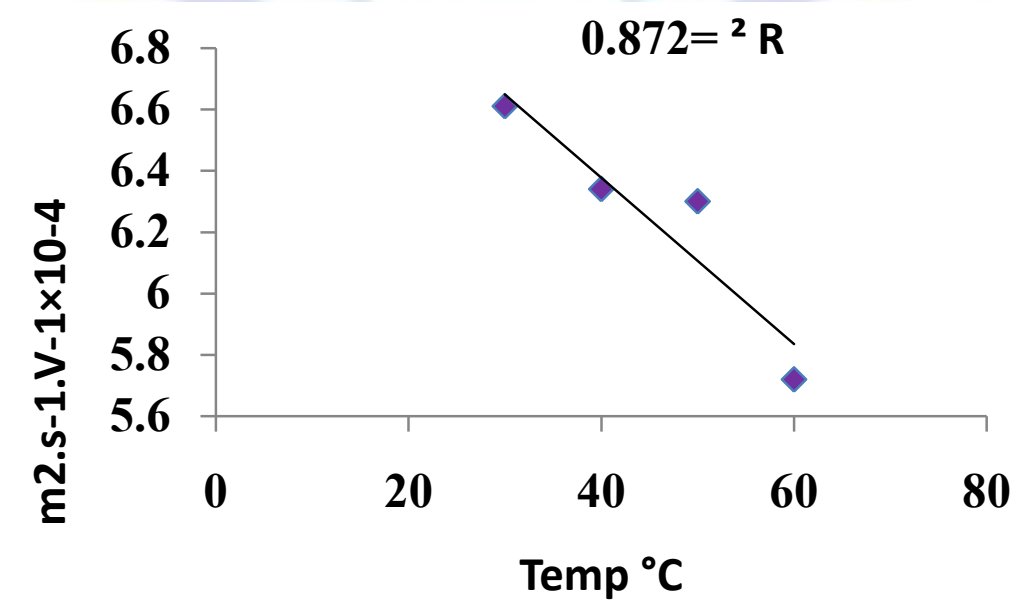

Figure 13: Variation of ionic mobility of $0.5 \mathrm{M} \mathrm{HCl}$ with temperature in presence of $30 \mathrm{ppm}$ paracetamol. 


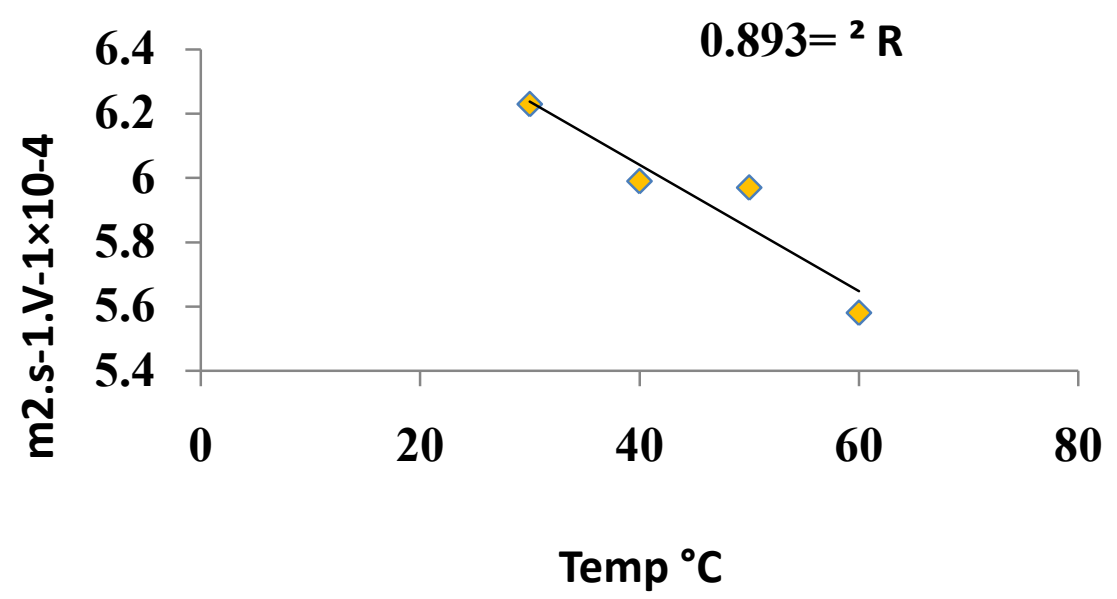

Figure 14: Variation of ionic mobility of $0.5 \mathrm{M} \mathrm{HCl}$ with temperature in presence of $40 \mathrm{ppm}$ paracetamol.

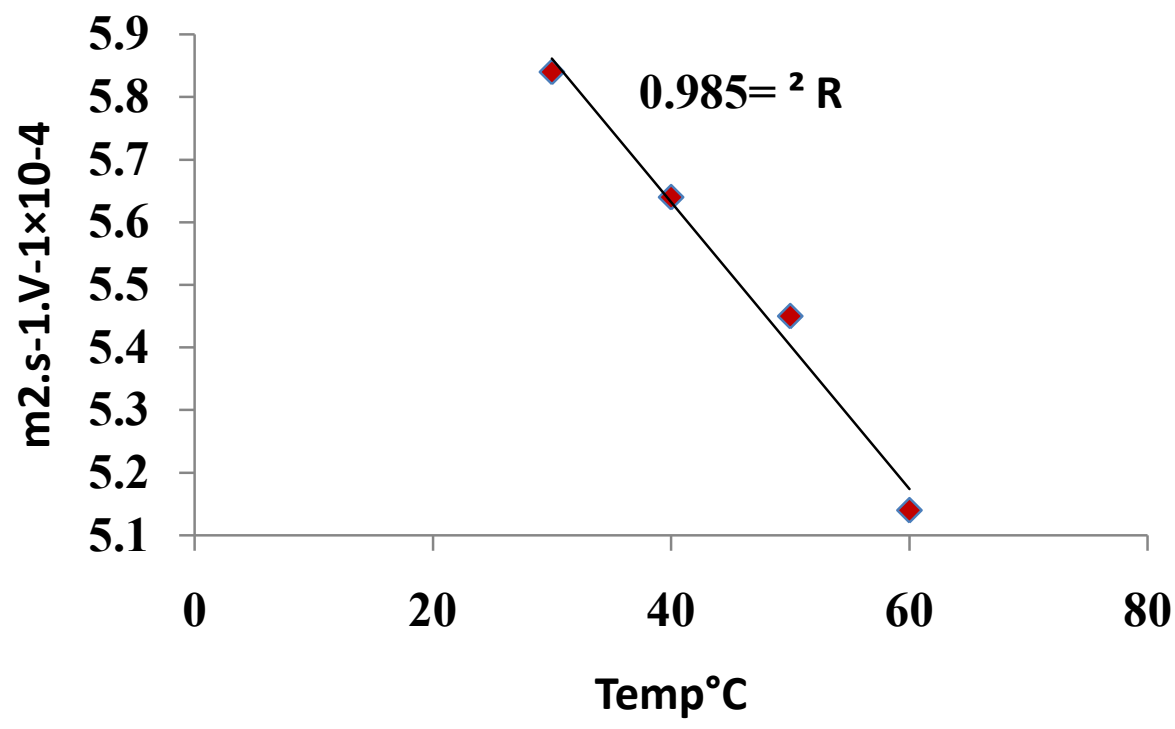

Figure 15: Variation of ionic mobility of $0.5 \mathrm{M} \mathrm{HCl}$ with temperature in presence of $50 \mathrm{ppm}$ paracetamol.

On the other hand, the increasing of inhibition efficiency with temperatures is predominant at all concentrations of paracetamol especially at higher concentration i.e., decreasing the activation energy that needed for paracetamol as temperature increase to reduce the molar conductance of acid hence, increasing the concentration of paracetamol make it has more strong ability to reduce the conductance of acid in other words increasing temperature leads increase the activation energy for acid ions to transport toward the oppose electrode in the conductance cell. The relation between inhibition efficiency and temperature is shown in Figures (16-20) below:

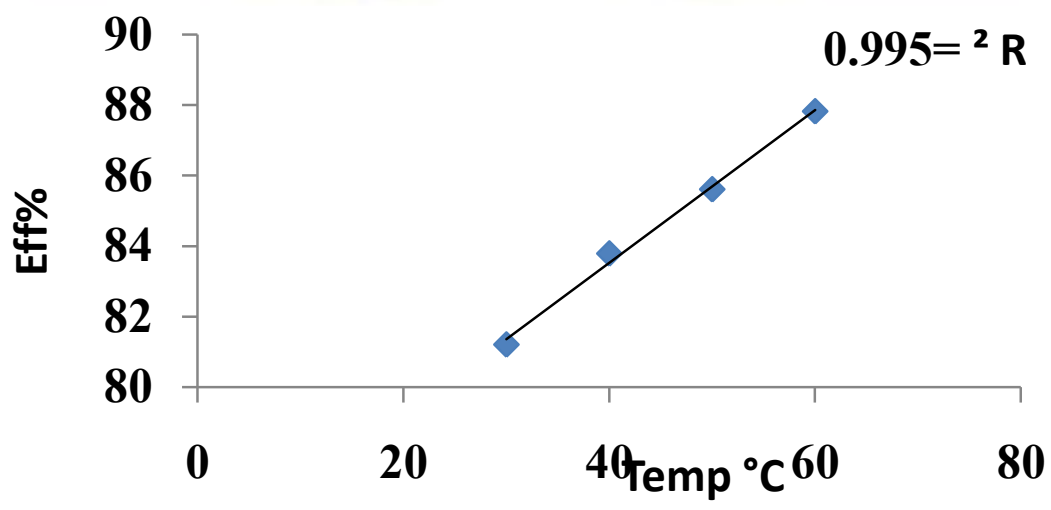

Figure 16: Variation of inhibition efficiency of $10 \mathrm{ppm}$ paracetamol against the molar conductance for $0.5 \mathrm{M} \mathrm{HCl}$ with temperature. 


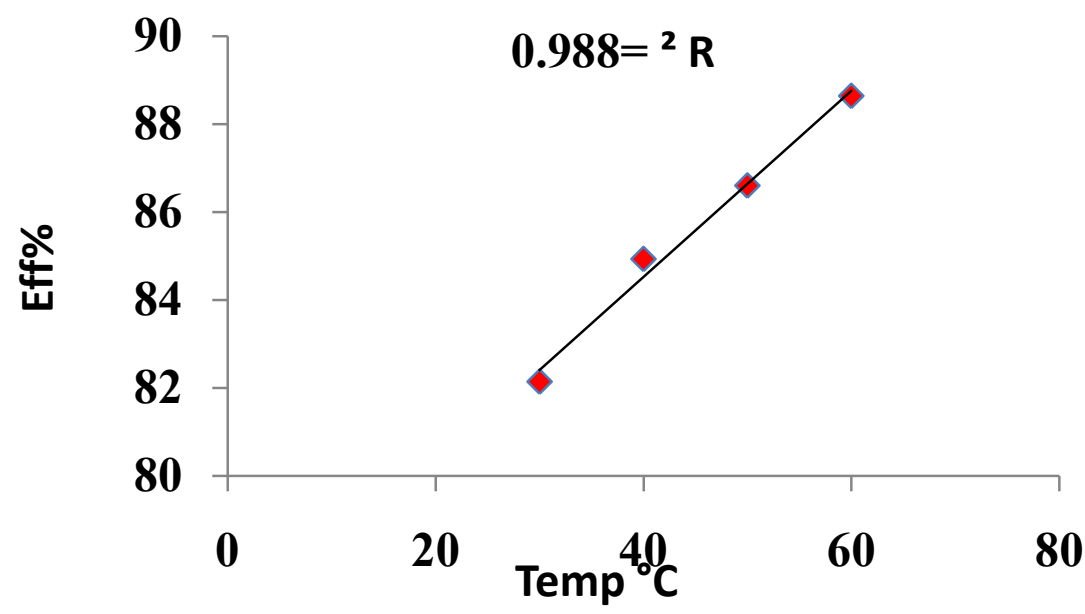

Figure 17: Variation of inhibition efficiency of $20 \mathrm{ppm}$ paracetamol against the molar conductance for $0.5 \mathrm{M} \mathrm{HCl}$ with temperature .

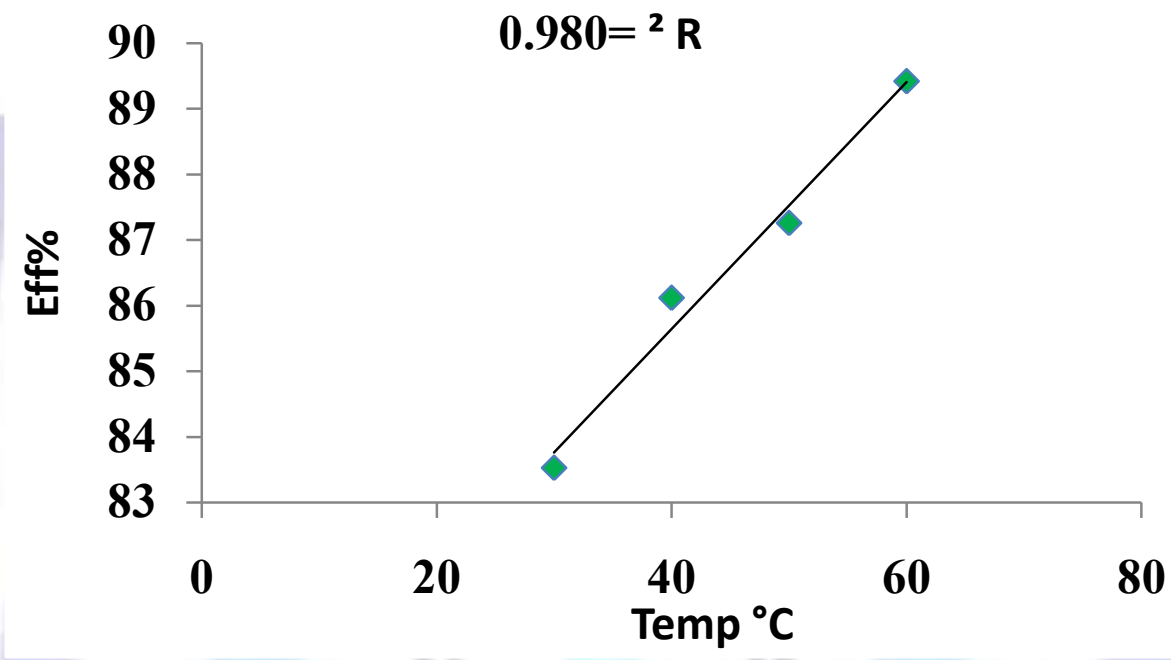

Figure 18: Variation of inhibition efficiency of $30 \mathrm{ppm}$ paracetamol against the molar conductance for $0.5 \mathrm{M} \mathrm{HCl}$ with temperature.

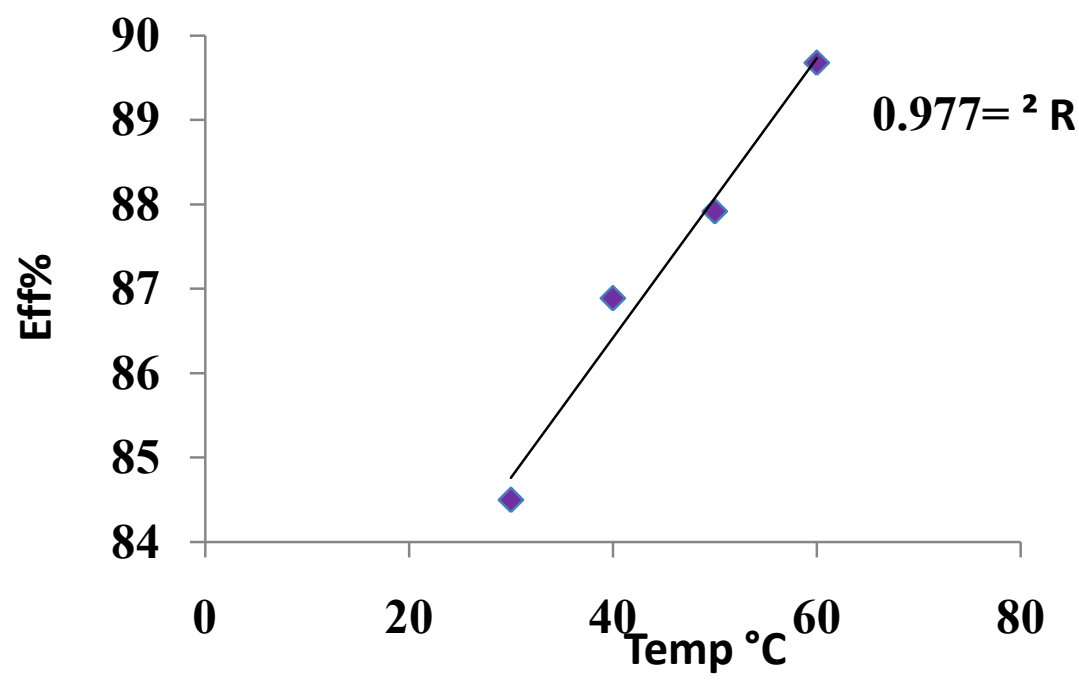

Figure 19: Variation of inhibition efficiency of $40 \mathrm{ppm}$ paracetamol against the molar conductance for $0.5 \mathrm{M} \mathrm{HCl}$ with temperature 


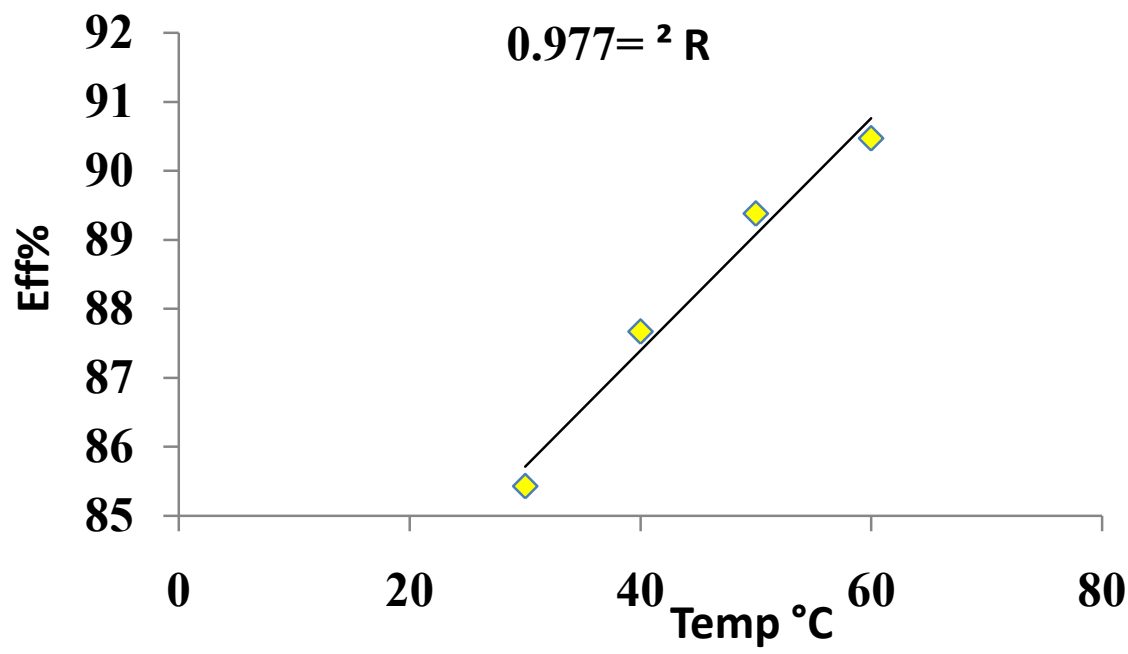

Figure 20: Variation of inhibition efficiency of $50 \mathrm{ppm}$ paracetamol against the molar conductance for $0.5 \mathrm{M} \mathrm{HCl}$ with temperature.

\section{Kinetic study:}

The molar conductance for hydrochloric acid in presence and absence of paracetamol can be studied kinetically at temperatures ranged (30-60) ${ }^{\circ} \mathrm{C}$ where, activation energy, enthalpy of activation, free energy of activation and entropy of activation are functions will be studied according to the particular equations i.e., Arrhenius equation is used to calculate the activation energy for hydrochloric acid in presence and absence of paracetamol where the molar conductance of the acid can be considered as a function of activation energy[22]:

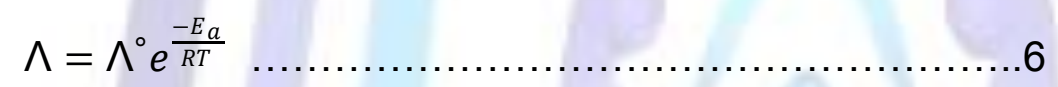

Where $\Lambda$ ia he molar conductance, $\Lambda$ i is the infinite molar conductance as Arrhenius constant, Ea is an activation energy in $\mathrm{kJ}$.mol-1, R is Molar gas constant (8.314 J k-1.mol-1) and T is the absolute Temperature in $\mathrm{k}$. Thus, Arrhenius equation is convert into natural logarithm for as below:

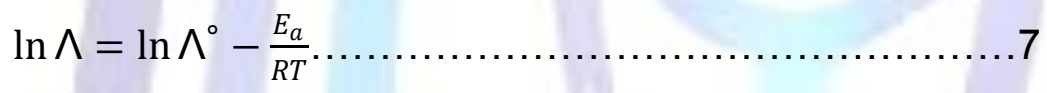

When the relation between $\ln (\Lambda)$ against inverse of absolute temperature, the yielded slope is an activation energy and the intercept is the Arrhenius constant. . Figures (21-26) explain the relation between $\ln \Lambda$ and the inverse of absolute temperature (Arrhenius equation) for $0.50 \mathrm{M} \mathrm{HCl}$ in presence and absence of different concentrations from the Paracetamol respectively:

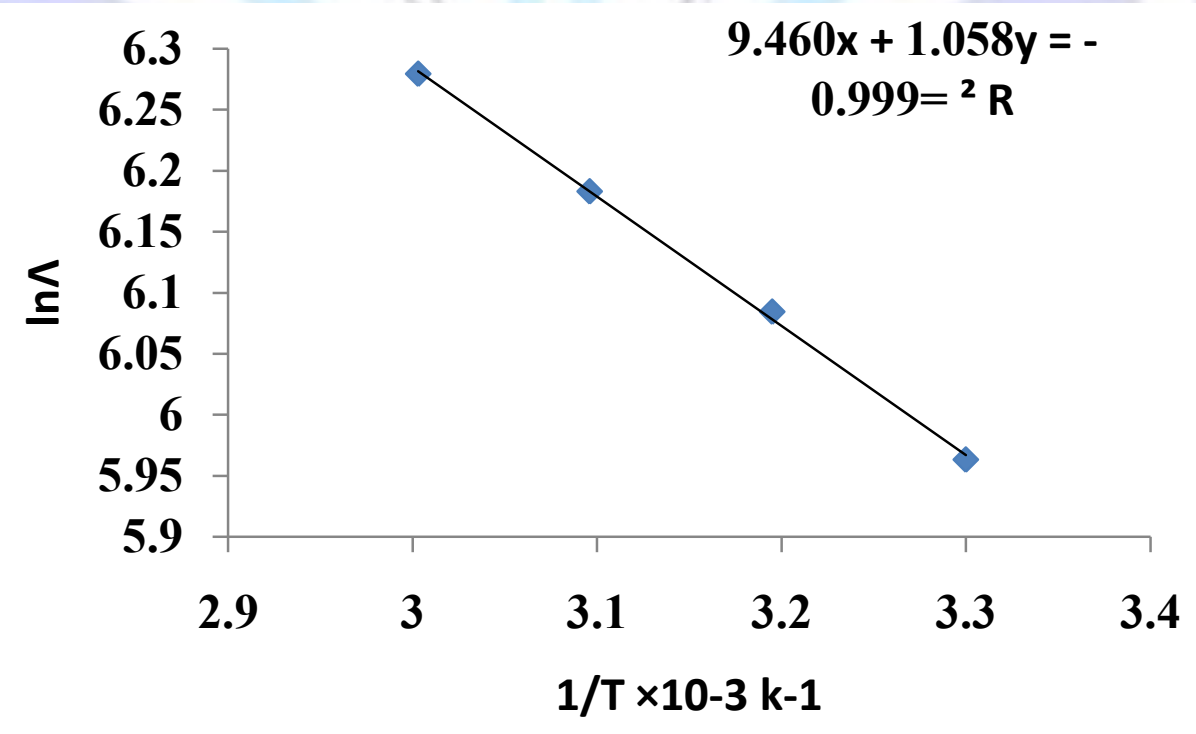

Figure 21: Arrhenius relationship for the molar conductance of $0.50 \mathrm{M} \mathrm{HCl}$ in absence of Paracetamol. 


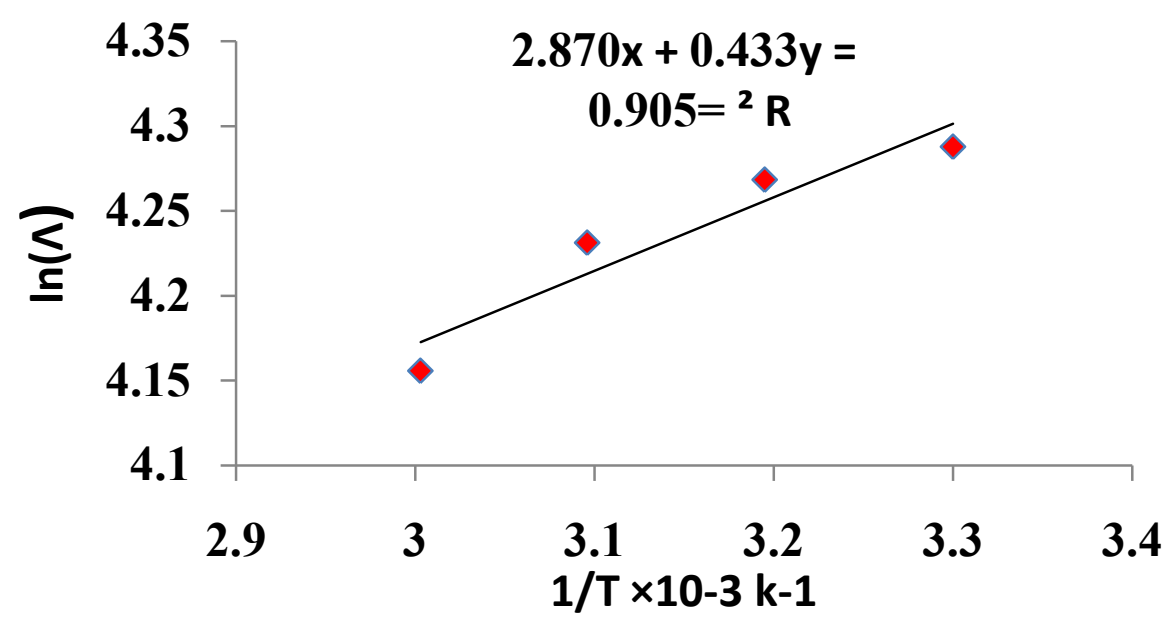

Figure 22: Arrhenius relationship for the molar conductance of $0.50 \mathrm{M} \mathrm{HCl}$ in presence of 10ppm Paracetamol.

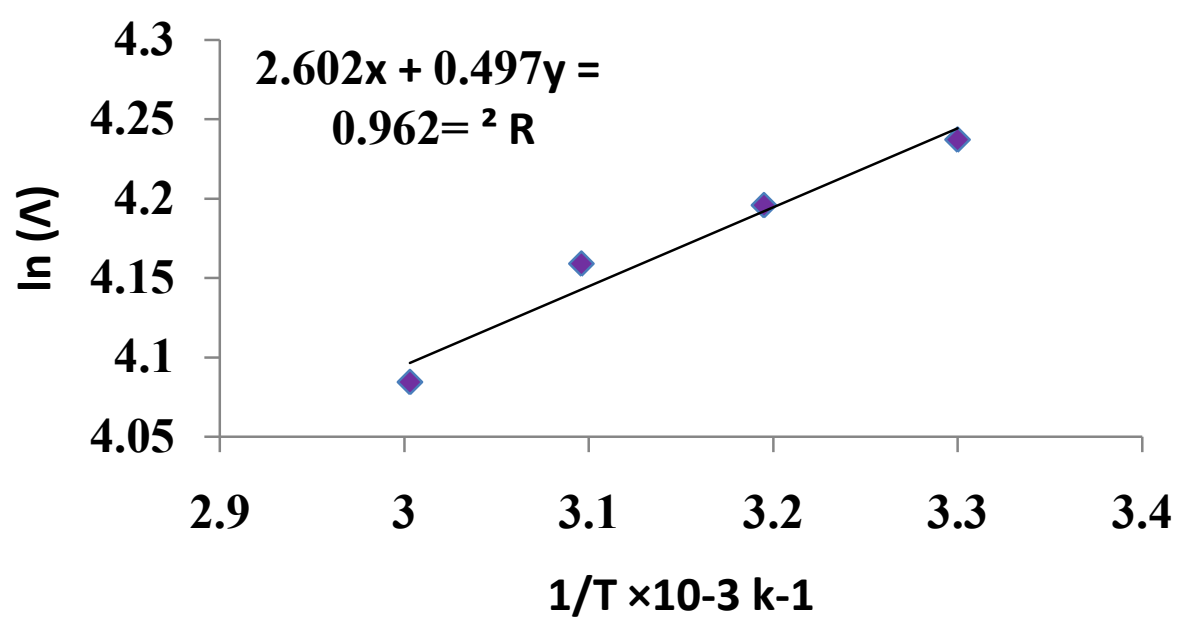

Figure 23: Arrhenius relationship for the molar conductance of $0.50 \mathrm{M} \mathrm{HCl}$ in presence of 20ppm Paracetamol.

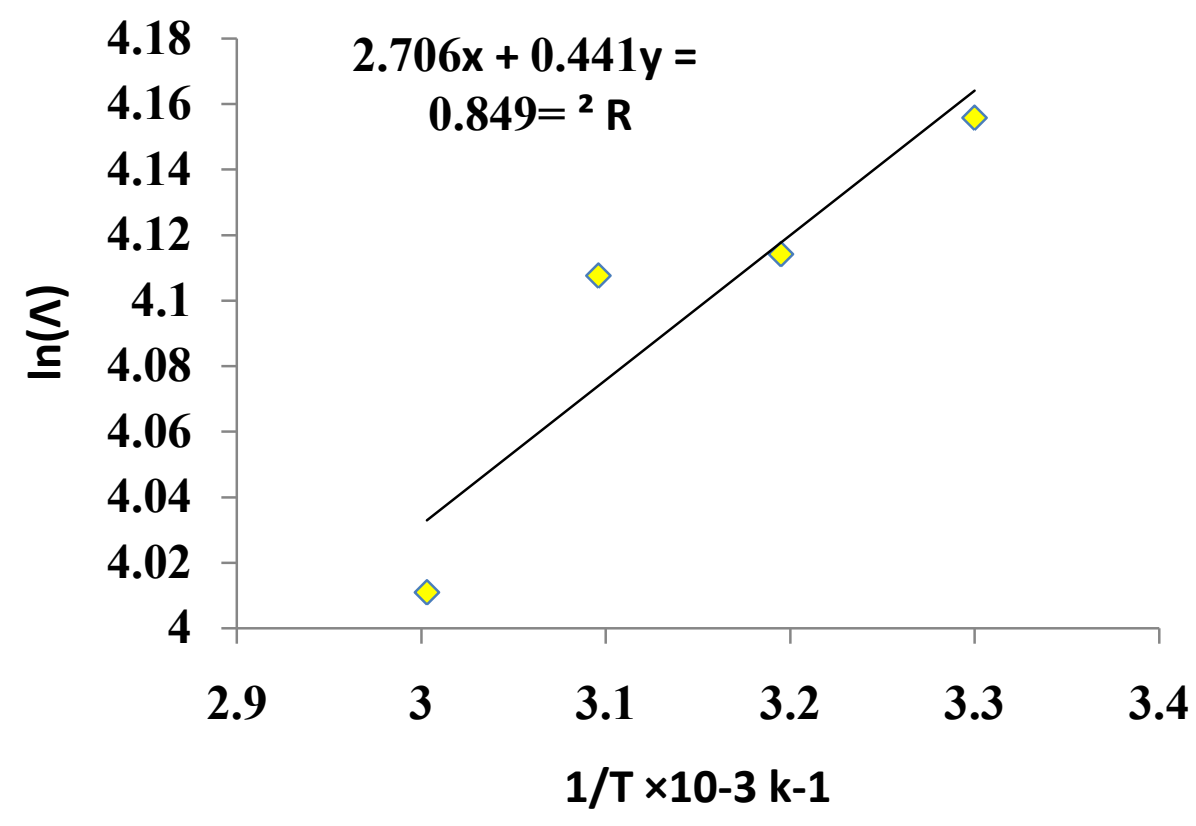

Figure 24: Arrhenius relationship for the molar conductance of $0.50 \mathrm{M} \mathrm{HCl}$ in presence of 30ppm Paracetamol. 


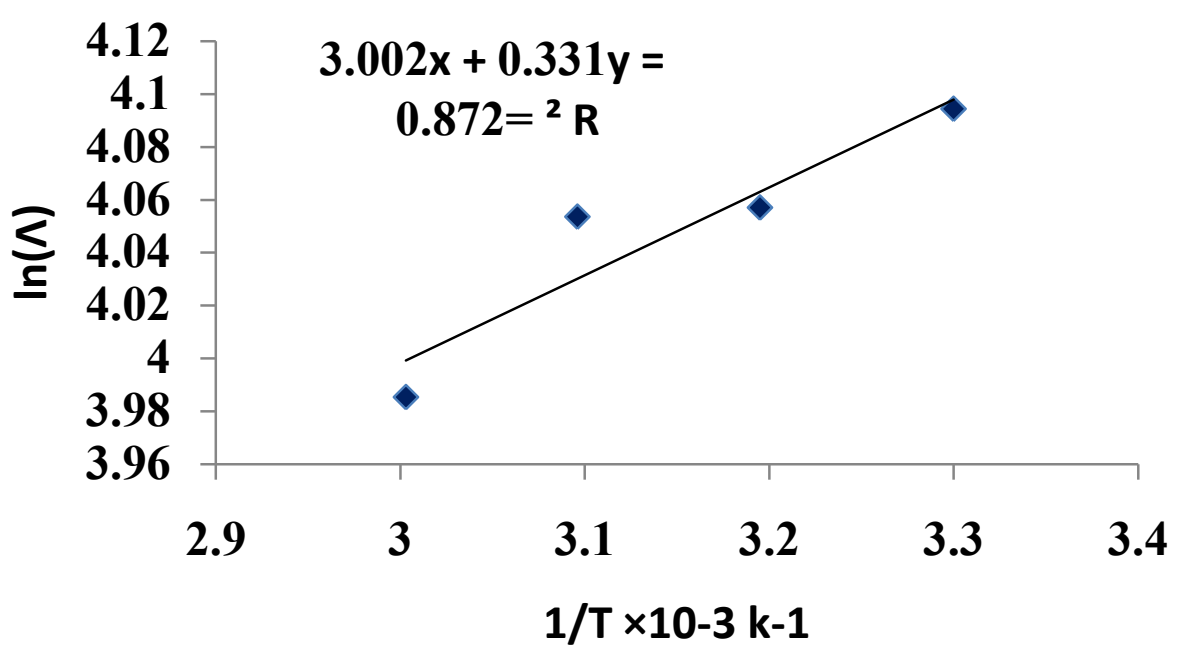

Figure 25: Arrhenius relationship for the molar conductance of $0.50 \mathrm{M} \mathrm{HCl}$ in presence of 40ppm Paracetamol.

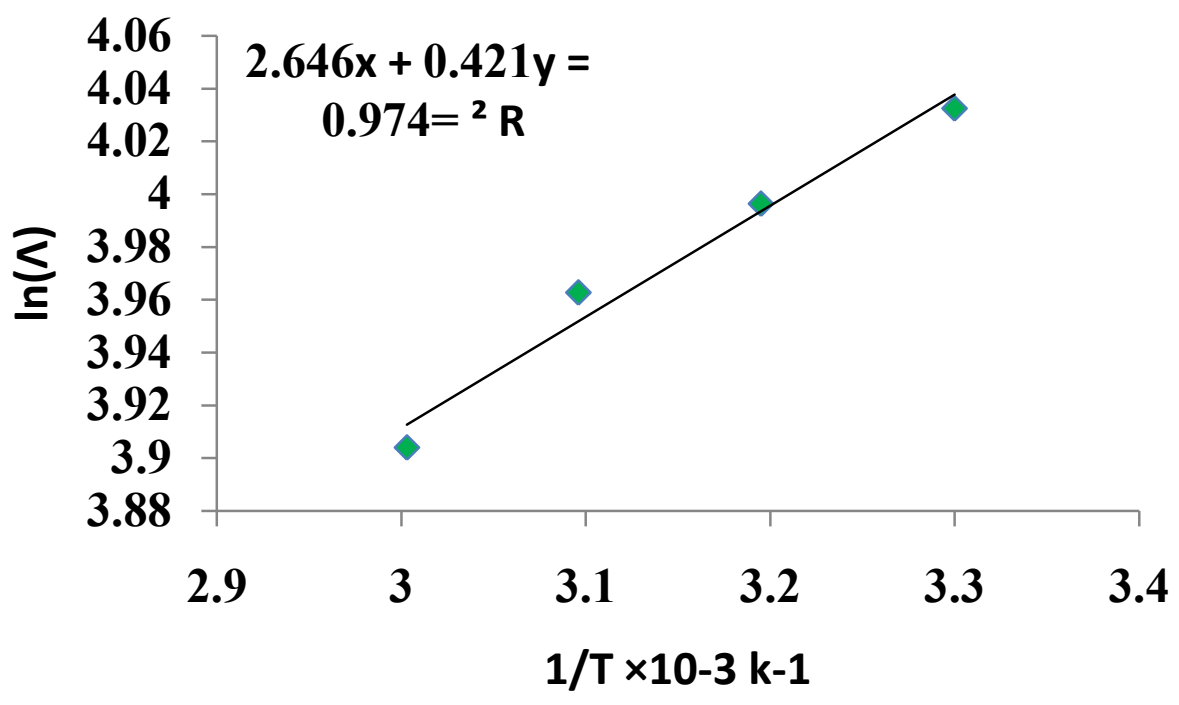

Figure 26: Arrhenius relationship for the molar conductance of $0.50 \mathrm{M} \mathrm{HCl}$ in presence of 50ppm Paracetamol.

Thus, enthalpy of activation is calculated according to the following equation which superimposed to Eyrlying equation:

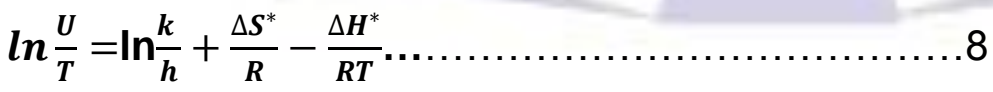

Where $\Delta \mathrm{H}^{*}$ and $\Delta \mathrm{S}^{*}$ are the enthalpy and entropy of activation in $\mathrm{kJ} / \mathrm{mol}$ and $\mathrm{J} \cdot \mathrm{k}^{-1} \cdot \mathrm{mol}^{-1}$ respectively, $\mathrm{k}$ is a Boltzmann constant and $U$ is the ionic mobility of hydrochloric acid. Furthermore, the free energy of activation $\Delta G^{*}$ is calculated according to the following equation:

$\Delta G^{*}=\Delta H^{*}-T \Delta S^{*}$ 9

Where $\Delta \mathrm{G}^{*}$ is the free energy of activation in $\mathrm{kJ} / \mathrm{mol}$. The calculation of enthalpy, entropy and free energy of activation can be explained in Figures (27-32) as below : 


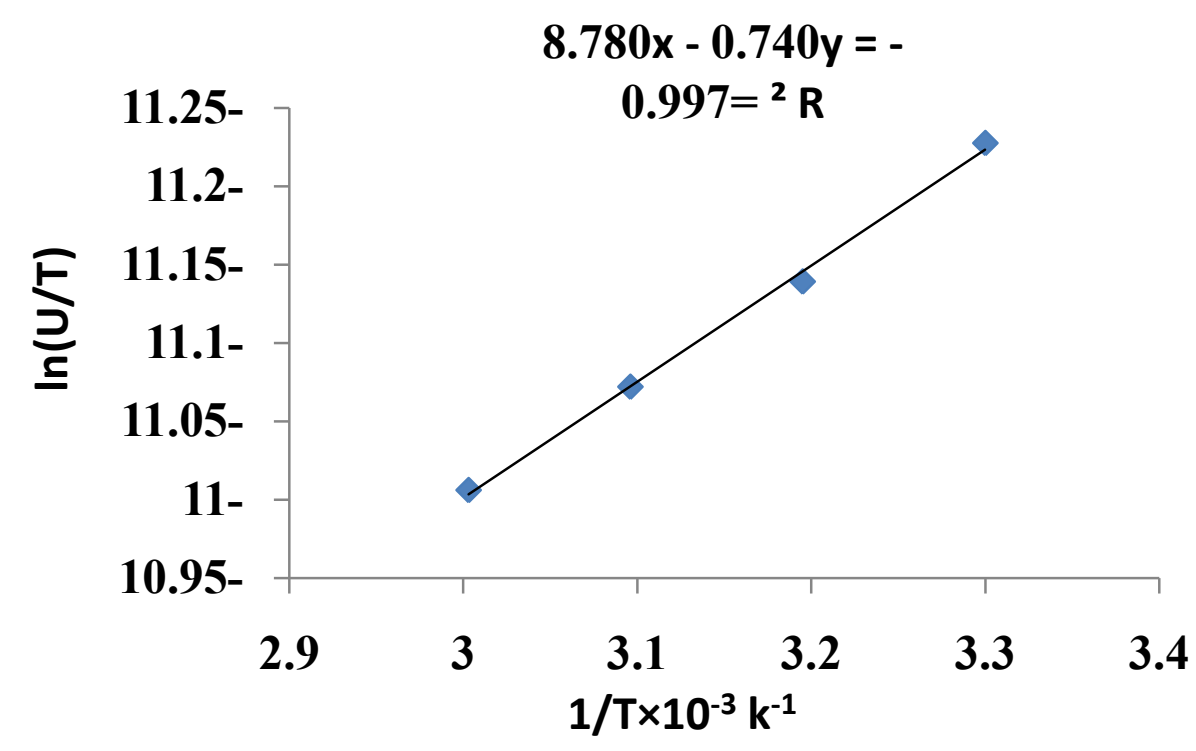

Figure 27: Calculation the activation parameters for $0.5 \mathrm{HCl}$ in absence of paracetamol.

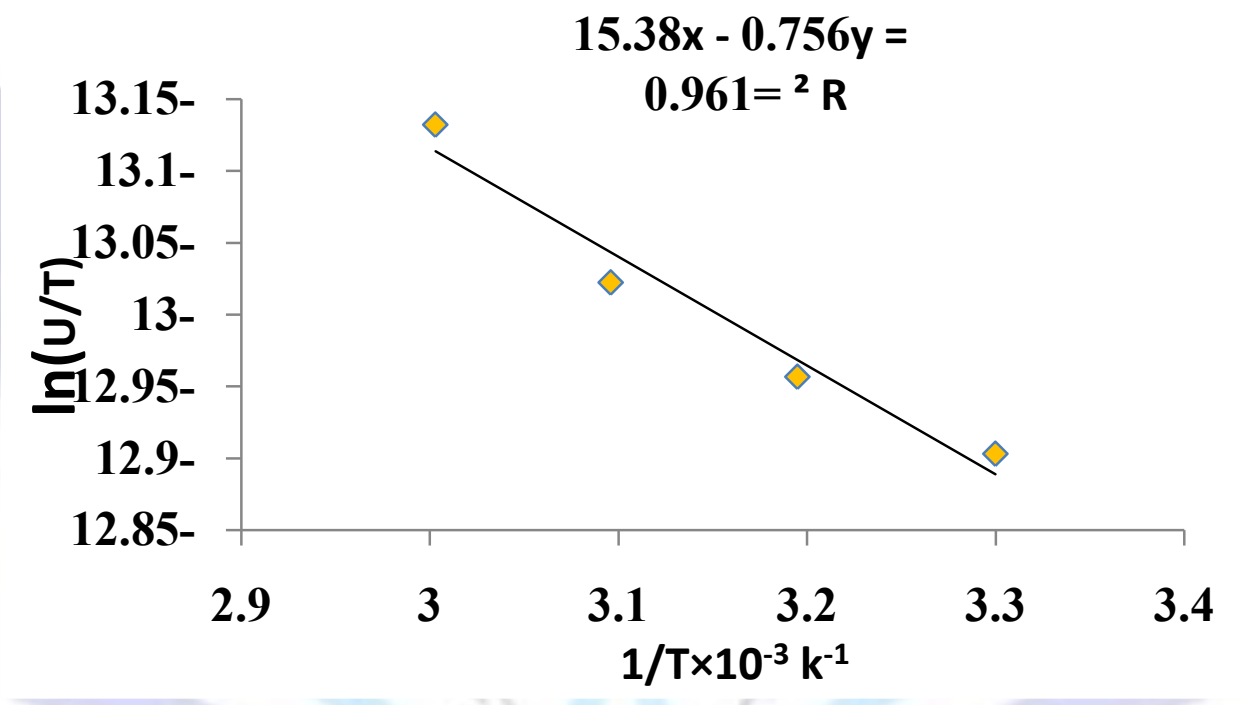

Figure 28: Calculation the activation parameters for $0.50 \mathrm{M} \mathrm{HCl}$ in presence of $10 \mathrm{ppm}$ paracetamol.

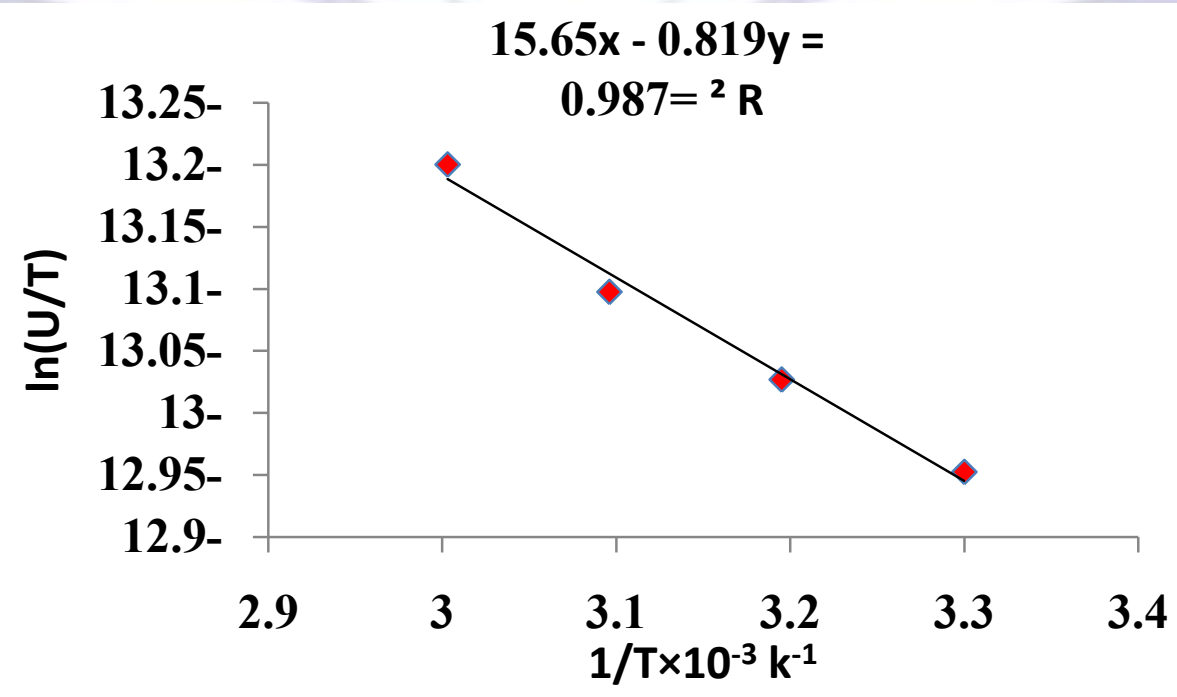

Figure 29: Calculation the activation parameters for $0.50 \mathrm{M} \mathrm{HCl}$ in presence of $20 \mathrm{ppm}$ paracetamol. 


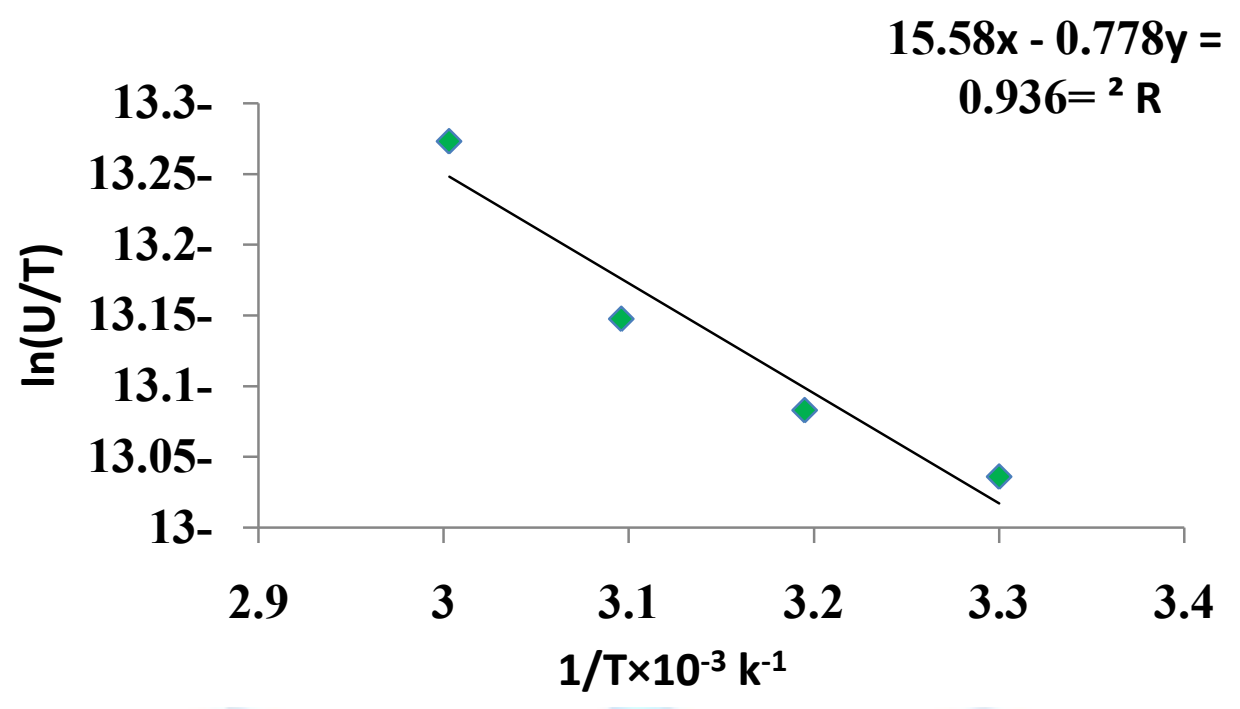

Figure 30: Calculation the activation parameters for $0.50 \mathrm{M} \mathrm{HCl}$ in presence of $30 \mathrm{ppm}$ paracetamol.

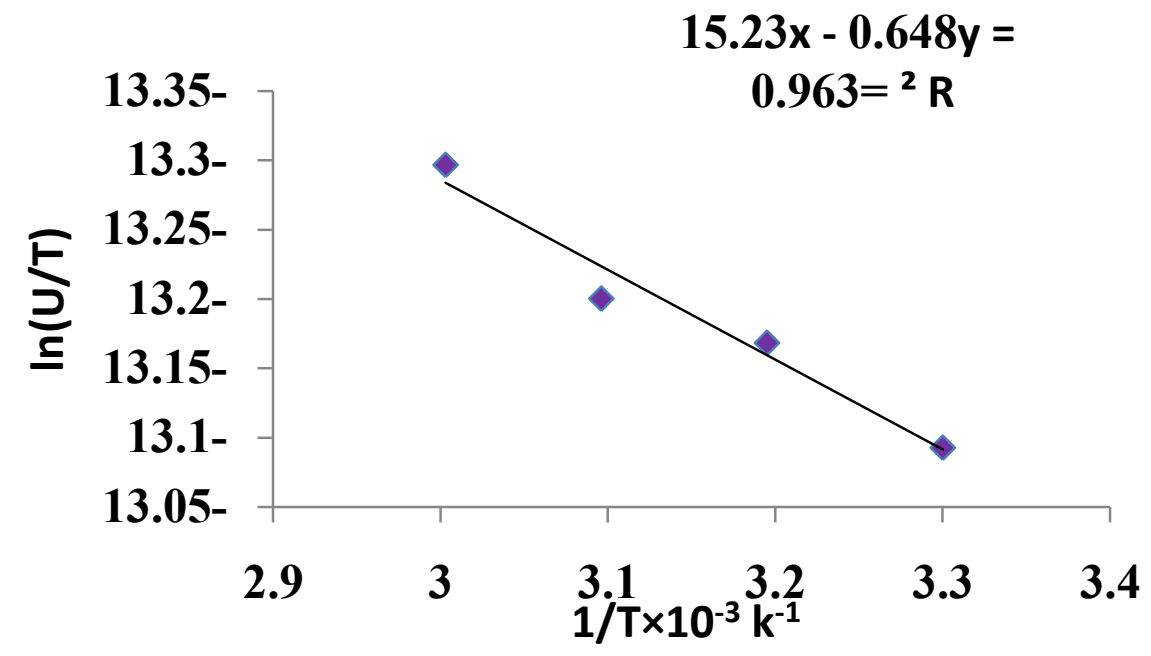

Figure 31: Calculation the activation parameters for $0.50 \mathrm{M} \mathrm{HCl}$ in presence of $40 \mathrm{ppm}$ paracetamol.

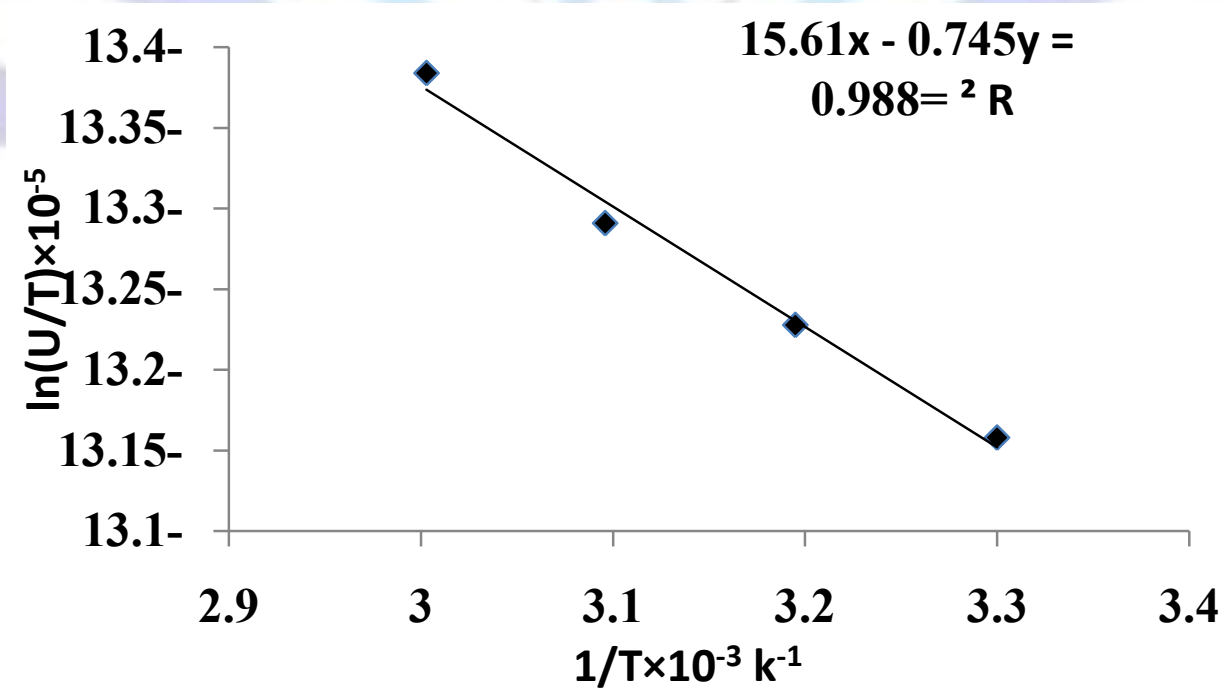

Figure 32: Calculation the activation parameters for $0.50 \mathrm{M} \quad \mathrm{HCl}$ in presence of $50 \mathrm{ppm}$ paracetamol. 
The kinetic activation functions is summarized in Table 12:

Table 12: Kinetic parameters for the conductance of $0.50 \mathrm{M} \mathrm{HCl}$ in presence and absence of different concentration of paracetamol.

\begin{tabular}{|l|l|l|l|l|l|l|l|}
\hline Compound & $\begin{array}{l}\text { Conc. } \\
(\mathrm{ppm})\end{array}$ & $\begin{array}{l}\mathrm{E}_{\mathrm{a}} \\
\left(\mathrm{kJ} \cdot \mathrm{mol}^{-1}\right)\end{array}$ & $\begin{array}{l}\mathrm{In}\left(\Lambda^{\circ}\right) \\
\mathrm{HCl}\end{array}$ & $\begin{array}{l}\Lambda^{\circ} \\
\Omega^{-1} \mathrm{~mol}^{-1} \cdot \mathrm{cm}^{2}\end{array}$ & $\begin{array}{l}\Delta \mathrm{H}^{\prime} \\
\left(\mathrm{kJ}^{\prime} \mathrm{mol}^{-1}\right)\end{array}$ & $\begin{array}{l}\Delta \mathrm{S}^{\prime} \\
\left(\mathrm{J} . \mathrm{mol}^{-1}\right)\end{array}$ & $\begin{array}{l}\Delta \mathrm{G}^{\prime} \\
\left(\mathrm{kJ}^{\prime} \mathrm{mol}^{-1}\right)\end{array}$ \\
\hline paracetamol & 10 & -3.600 & 2.870 & 17.637 & -6.285 & -325.410 & 92.314 \\
\hline paracetamol & 20 & -4.132 & 2.602 & 13.491 & -6.809 & -327.655 & 92.470 \\
\hline paracetamol & 30 & -3.666 & 2.706 & 14.969 & -6.468 & -327.073 & 92.635 \\
\hline paracetamol & 40 & -2.752 & 3.002 & 20.126 & -5.387 & -324.163 & 92.834 \\
\hline paracetamol & 50 & -3.500 & 2.646 & 14.098 & -6.193 & -327.322 & 92.986 \\
\hline
\end{tabular}

Table 12 reveal that all functions of activation like energy of activation. Enthalpy of activation and energy of activation are positive i.e., endothermic and non-spontaneous process that corresponding with the highly value of infinite molar conductance $\left(\Lambda^{\circ}\right)$ in the mentioned table. When the paracetamol is present, the activation energy will become negative that means the molar conductance process is reduced in presence of paracetamol and this process is reduced as the concentration of paracetamol is increased which can be indicated by reducing in $\left(\Lambda^{\circ}\right)$ values i.e., the molar conductance of acid decreases with increase in temperature in presence of all concentrations for paracetamol this corresponding to negative values for enthalpy of activation in presence of different concentration of paracetamol that can be attributed to the heat of adsorption for paracetamol becomes larger than the activation energy of the intrinsic kinetic for the molar conductance for the hydrochloric acid i.e., The negative apparent electrochemical enthalpy of activation can be explained by a sufficiently negative enthalpy for the preceding adsorption equilibrium, which can lead to a negative apparent electrochemical enthalpy of activation for the overall process[22]. On the other hand, the free energy of activation for the molar conductance of hydrochloric acid in presence of paracetamol will become more non-spontaneous which meant reducing the molar conductance in presence of. On the other hand, the negative values of entropy of activation is increased as concentration of paracetamol increased insist that the mobility of both chloride and hydrogen ions toward the oppose electrodes in conduction cell is retarded by the paracetamol[17].

\section{Thermodynamic studies:}

In this paragraph, thermodynamic functions like enthalpy of adsorption $\Delta \mathrm{H}_{\mathrm{ads}}$, free energy of adsorption $\Delta \mathrm{G}_{\mathrm{ads}}$ and entropy of Adsorption $\Delta \mathrm{S}_{\text {ads }}$ will be calculated related to the isotherms of adsorption as below:

Basic information on the interaction between the inhibitor and the alloy surface can be provided by the adsorption isotherm. In order to obtain the isotherm, the fractional coverage values $\theta$ as a function of inhibitor concentration must be obtained. It well known that $\theta$ can be obtained from the corrosion current via [23]:

$\theta=\frac{\Lambda_{\text {Blank }}-\Lambda_{\text {In hibitor }}}{\Lambda_{\text {Blank }}}$

Where $\theta$ is the value of retardation of hydrogen and chloride ions in hydrochloric acid to mobile toward the oppose electrode by paracetamol

The $\theta$ values obtained in this way are shown in Table 13.

Attempts were made to fit these $\theta$ values to various isotherms including Frumkin, Langmuir,Temkin, and Freundlisch. Many adsorption isotherms were plotted for the paracetamol and the best isotherm for each one of them was selected according to the $R^{2}$ that has value near to unity value, According to $\theta$ is related to equilibrium adsorption constant(K and concentration of inhibitor morality $\mathrm{C}$ via

$\theta=\left(\frac{-1}{2 f}\right) \times\left[\ln (C)-\left(\ln \left[\frac{\theta}{1-\theta}\right]+\left(\frac{-1}{2 f}\right) \ln K_{a d s}\right.\right.$ 11

(Frumkin adsorption isotherm) where f factor of energetic inhomogenity

$\theta=K_{a d s} \times C$ .12 (Freundlich adsorption isotherm) 
$\theta=\left(\frac{-1}{f}\right) \times \ln K_{a d s}+\left(\frac{-1}{f}\right) \times \ln (C)$

Timken adsorption isotherm, where $f$ factor of energetic inhomogenity.

$\log \theta=n \log C+\log K_{a d}$

Langmuir adsorption isotherm . From the above equations, the equilibrium constant of adsorption can be calculated, then the standard energy of adsorption, $\Delta \mathrm{G}^{\circ}$ ads by [24]:

$K=\frac{1}{55.5} \times \exp \frac{\left(-\Delta G_{a d s}^{\circ}\right)}{R T}$. 15

where the value 55.5 is the concentration of water in the solution in mol.dm-3, $\mathrm{K}$ is the equilibrium constant of adsorption, $\mathrm{C}$ is the concentration in molarity.

Table 13. Concentration dependence of the surface coverage $(\theta)$ values at different concentrations for paracetamol inhibitor in $0.50 \mathrm{M} \mathrm{HCl}$ solution at different temperatures.

\begin{tabular}{|l|l|l|l|l|}
\hline $\begin{array}{l}\text { Conc } \\
\mathrm{mol} / / \times 10^{-5}\end{array}$ & $30^{\circ} \mathrm{C}$ & $40^{\circ} \mathrm{C}$ & $50^{\circ} \mathrm{C}$ & $60^{\circ} \mathrm{C}$ \\
\hline 6.623 & 0.8121 & 0.8379 & 0.8561 & 0.8782 \\
\hline 13.246 & 0.8214 & 0.8493 & 0.8660 & 0.8864 \\
\hline 19.869 & 0.8353 & 0.8612 & 0.8726 & 0.8942 \\
\hline 26.492 & 0.8450 & 0.8689 & 0.8792 & 0.8968 \\
\hline 33.115 & 0.8543 & 0.8767 & 0.8639 & 0.9047 \\
\hline
\end{tabular}

The adsorption isotherms can be shown in Figures (33-36) below:

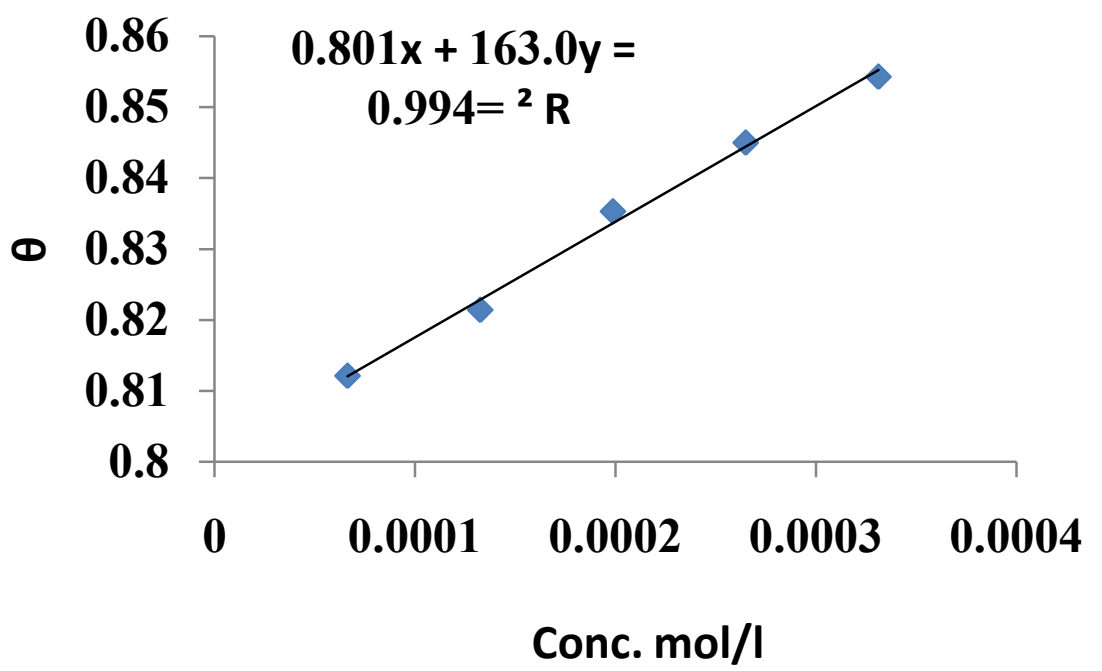

Figure 33: Freundlisch adsorption isotherm for paracetamol as inhibitor against the molar conductance of $0.50 \mathrm{M}$ $\mathrm{HCl}$ solution at $30^{\circ} \mathrm{C}$. 


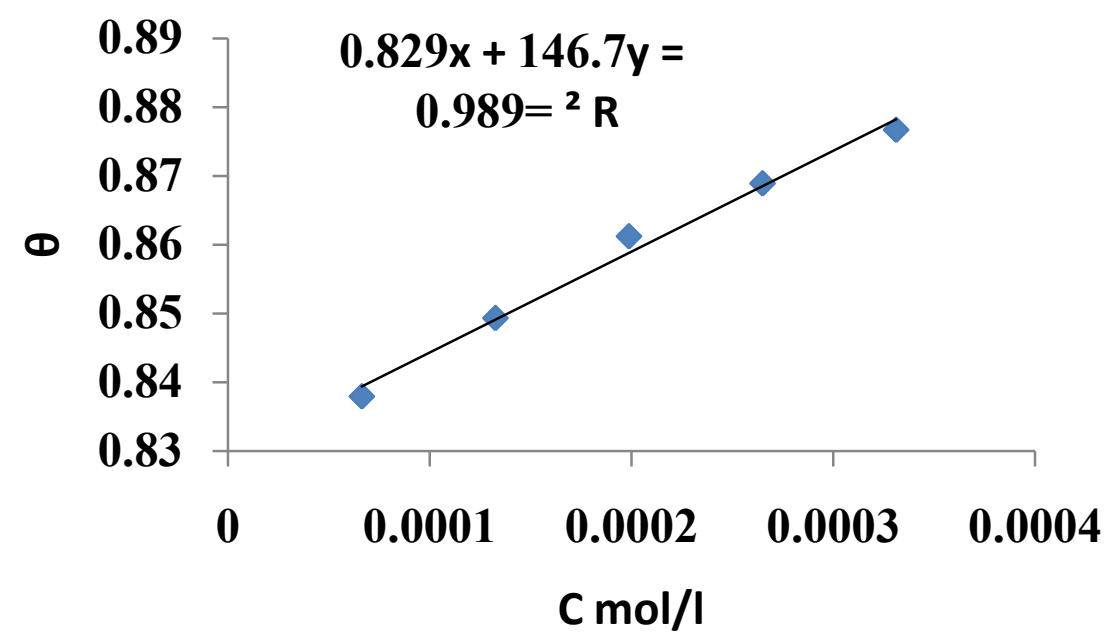

Figure 34: Freundlisch adsorption isotherm for paracetamol as inhibitor against the molar conductance of $0.50 \mathrm{M}$ $\mathrm{HCl}$ solution at $40^{\circ} \mathrm{C}$.

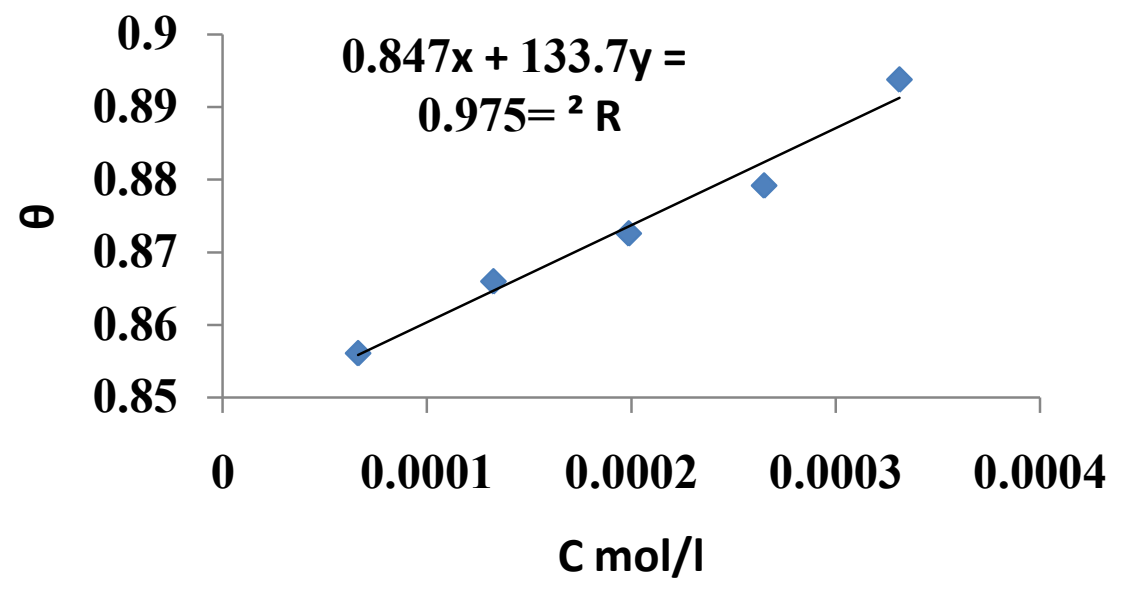

Figure 35: Freundlisch adsorption isotherm for paracetamol as inhibitor against the molar conductance of $0.50 \mathrm{M}$ $\mathrm{HCl}$ solution at $50^{\circ} \mathrm{C}$.

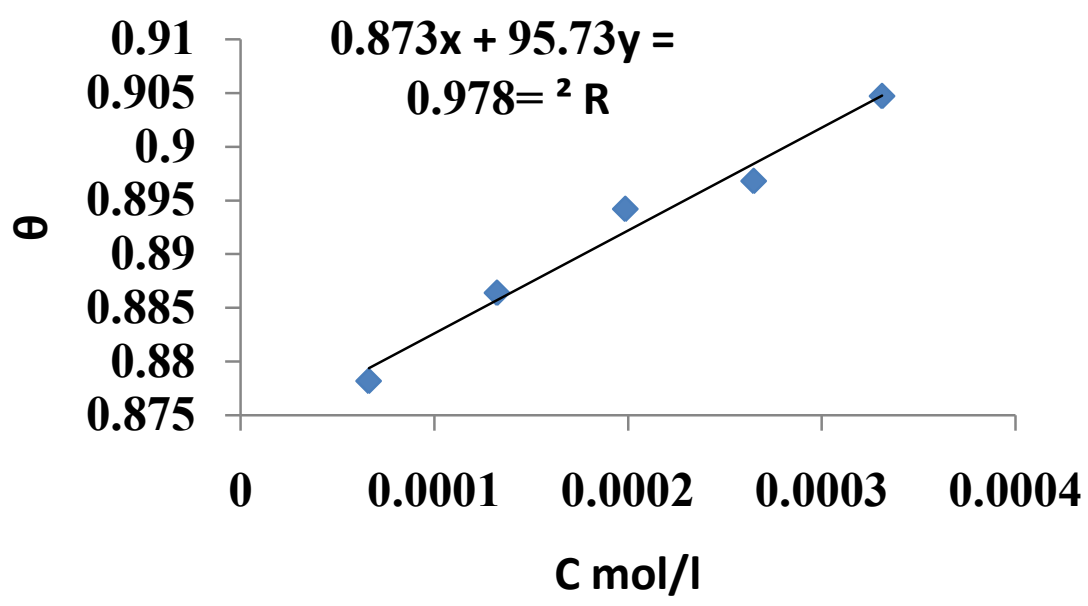

Figure 36: Freundlisch adsorption isotherm for paracetamol as inhibitor against the molar conductance of $0.50 \mathrm{M}$ $\mathrm{HCl}$ solution at $60^{\circ} \mathrm{C}$.

Figures (33-36) show the type of adsorption isotherm for Paracetamol as inhibitor in $0.50 \mathrm{M} \mathrm{HCl}$ at temperature ranged $(30-60)^{\circ} \mathrm{C}$. The data are fitted to the Frumkin, Freundlisch Timken and Langmuir adsorption isotherms by using regression 
methods then $\mathrm{K}$ and $\Delta \mathrm{G}^{\circ}$ ads can be obtained. Generally, at all temperatures paracetamol obey to Freundlisch isotherm of adsorption as shown above The correlation coefficient $\left(R^{2}\right)$ was used to choose the isotherm that best fit experimental data for each one of the temperatures in this study[25]. Hence, the equilibrium constant, free energy of adsorption $\Delta \mathrm{G}^{\circ}{ }_{\text {ads }}$, enthalpy of adsorption $\Delta \mathrm{H}^{\circ}$ ads and entropy of adsorption $\Delta \mathrm{S}^{\circ}$ ads where, the following equation can be used to calculate a thermodynamic functions:

$\frac{\Delta G_{a d s}^{\circ}}{T}=\frac{\Delta H_{a d s}^{\circ}}{T}+k$

The variation of $\Delta G^{\circ}$ ads $/ T$ with $1 / T$ gives a straight line with a slope that equals $\Delta H^{\circ}$ ads (Figure 37) . It can be viewed from the Figure that $\Delta G^{\circ}$ ads $/ T$ decreases with $1 / T$ in a linear manner. The calculated values are shown in Table 14 . The adsorption heat could be approximately regarded as the standard adsorption heat under experimental conditions. The negative sign of $\Delta \mathrm{H}^{\circ}$ ads in $\mathrm{HCl}$ solution indicates that the adsorption of inhibitor molecule is an exothermic process[24].

Table 14: Thermodynamic parameters for the adsorption of paracetamol in $0.50 \mathrm{M} \mathrm{HCl}$ at different temperatures.

\begin{tabular}{|l|l|l|l|l|}
\hline Temp .k & $\mathrm{K}$ & $\Delta \mathrm{G}^{\circ}$ ads $\left(\mathrm{kJ}^{\mathrm{m}} \mathrm{mol}^{-1}\right)$ & $\Delta \mathrm{H}_{\text {ads }}\left(\mathrm{kJ} . \mathrm{mol}^{-1}\right)$ & $\Delta \mathrm{S}^{\circ}{ }_{\text {ads }}\left(\mathrm{J} . \mathrm{mol}^{-1}\right)$ \\
\hline 303 & 163.000 & -22.950 & -14.07 & 29.307 \\
\hline 313 & 146.700 & -23.433 & -14.07 & 29.914 \\
\hline 323 & 133.700 & -23.932 & -14.07 & 30.533 \\
\hline 333 & 95.73 & -23.748 & -14.07 & 29.063 \\
\hline
\end{tabular}

On the other hand, enthalpy of adsorption is calculated according to equation 16 as shown in Figure 37 below:

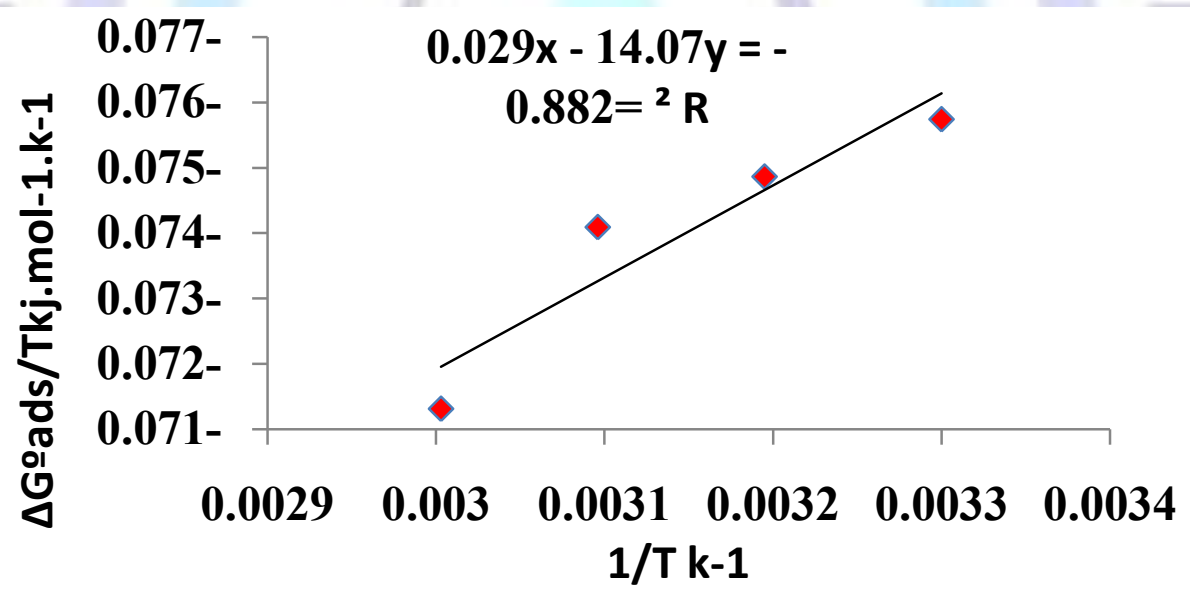

Figure 37. Adsorption isotherm plot for $\Delta \mathrm{Gads} / \mathrm{T}$ vs. $1 / \mathrm{T}$.

Then the standard adsorption entropy $\Delta S^{\circ}$ ads was obtained using the thermodynamic basic equation:

$\Delta G_{a d s}^{\circ}=\Delta H_{a d s}^{\circ}-T \Delta S_{a d s}^{\circ}$

The negative values of free energy of adsorption $\left(\Delta G^{\circ}\right.$ ads $)$ indicate that the adsorption process is spontaneous and the adsorbed layer on paracetamol surface is stable $[26,27]$. On the other hand, exothermic adsorption reaction data are obtained in addition to $\Delta S^{\circ}$ ads values in the presence of paracetamol are positive, meaning a disordering in presence of inhibitor is increased in order to the inhibitor is adsorbed on the metal surface. On the other hand, when the data in Table 14 is compared with the inhibition efficiency in Tables 6-11 indicate that increasing in efficiency as temperature increased which is attributed to chemical adsorption mode, thus, at high degree of coverage, the diffusion through the surface layer containing the inhibitor and corrosion products become the rate determining step of the metal dissolution process i.e., the adsorption mode for paracetamol is chemisorptions mode[28].

\section{CONCLUSION :}

There are several conclusions can be summarized as below:

1. Paracetamol acts as a good retarder for the molar conductance of $0.50 \mathrm{M} \mathrm{HCl}$ at different concentration i.e., (1050) ppm at constant temperature where as the concentration of paracetamol increased, the molar conductance of acid increased at all temperatures tin this study.

2. The molar conductance of acid is reduced as temperature increased in range $(30-60){ }^{\circ} \mathrm{C}$ reducing the molar conductance is $90.47 \%$ which encourage us to use the paracetamol as corrosion inhibitor for the metals or alloys in acidic media. 
3. It is noticed that the activation energy for the molar conductance of acid become a negative in presence of paracetamol compared with its value in absence of paracetamol (positive) which meant the paracetamol has the strong ability to inhibit the conductance of acid which correspond with the negative values for the enthalpy of activation for the molar conductance of acid due to the heat or enthalpy of adsorption process of $\mathrm{HCl}$ on the paracetamol is greater than the activation process for the molar conductance of acid.

4. The free energy of activation for the molar conductance of acid is positive whether in presence or absence of paracetamol but, the non-spontaneous property is increased in presence of paracetamol at all its concentrations.

5. The entropy of activation for the molar conductance of acid is negative whether in presence or absence of paracetamol but it increased as the paracetamol is present which meant that an order for the mobility of both hydrogen and chloride ions are taken placed i.e., the mobility of both ions are restricted.

6. The adsorption of paracetamol is obey to Freundlisch adsorption isotherm at all temperatures that ranged (3060) ${ }^{\circ} \mathrm{C}$ where, the equilibrium constant of adsorption is reduced as temperature increased, the adsorption process become more spontaneous and an exothermic adsorption process which accompanied by the positive entropy values.

\section{References:}

1. Shivapura S. Shivakumar, Kikkeri N. Mohana Int. J. Electrochem. Sci., 7 (2012) 1620 - 1638

2. N.A. Negm, Y.M. Elkholy, M.K. Zahran and S.M. Tawfik, Corros. Sci. 52 (2010) 3523

3. J. De Damborenea, J.M. Bastidas and A.J. Vazquez, Electrochim. Acta. 42 (1997) 455

4. S.S. Abd El Rehim, M.A.M. Ibrahim, and K.F. Khaled, J. Appl. Electrochem. 29 (1999) 593

5. N.A. Negm, Y.M. Elkholy, M.K. Zahran and S.M. Tawfik, Corros. Sci. 52 (2010) 3523

6. J. De Damborenea, J.M. Bastidas and A.J. Vazquez, Electrochim. Acta. 42 (1997) 455

7. 9. R. Solmaz, G. Kardas, B. Yazici and M. Erbil, Prot. Met. 41 (2005) 581

8. G.N. Mu, X.M. Li and F. Li, Mater. Chem. Phys. 86 (2004) 59

9. F. Bentiss, M. Bouanis, B. Mernari, M. Traisnel and M. Lagrenee, J. Appl. Electrochem. 32 (2002) 671

10. E.E. Ebenso, Mater. Chem. Phys. 79 (2003) 58

11. D.D.N. Singh, T.B. Singh and B. Gaur, Corros. Sci. 37 (1995) 1005

12. M. Hosseini, S.F.L. Mertens, and M.R. Arshadi, Corros. Sci. 45 (2003) 1473.

13. I. Ahamad1, R. Prasad, Eno E. Ebenso, M.A. Quraishi1, Int. J. Electrochem. Sci., 7 (2012) 3436 - 3452 .

14. Y. H. Ahmad, A. S. Mogoda, A. G. Gadallh , Int. J. Electrochem. Sci., 7 (2012) 4929 - 4941.

15. R.T. Loto1 and C.A. Loto, Int. J. Electrochem. Sci., 7 (2012) 9423 - 9440.

16. I.B. Obot a, S. A Umoren *a, N.O. Obi-Egbedi, J. Mater.Environ. Sci. 2 (1) (2011) 60-71.

17. Hadi.Z.AL-Sawaad, Int. J. Electrochem. Sci., 8 (2013) 3105 - 3120

18. Emerson Process Management, http://www.raihome.com, January 2010.

19. D61M002 • Printed by Radiometer Analytical SAS • France • 2004-05B.www.radiomeer analytical.com.

20. Mohammed Khair E.A. Al-Shwaiyat, Jordan Journal of Chemistry Vol. 8 No.2, 2013, pp. 79-89.

21. N.Vaszilcsina, V. Ordodib and A. Borzaa, International Journal of Pharmaceutics 431 (2012) 241- 244.

22. http://answers.yahoo.com.mady, article, 2,November, 2010.

23. Hadi Z.M. Al-Sawaad, J. Mater. Environ. Sci. 2 (2) (2011) 128-147.

24. Kaminski, M., Szklarska-Smialowska, Z., Corros. Sci.13 (1973) 557.

25. Bouklah, M., Hammouti, B., Lagrenee, M., Bentiss, F., Corros. Sci. 48 (2006) 2831.

26. E. Khamis, F. Bellucci, R.M. Latanision, E.S.H. El-Ashry, Corrosion 47 (1991) 677

27. Y. H. Ahmad, A. S. Mogoda, A. G. Gadallh, Int. J. Electrochem. Sci., 7 (2012) $4929-4941$

28. C.Jeyaprabha, S.Sathiyanarayanan, G.Venkatachari, "Electr.Chem .Acta", 51(2006). 